RUDIGER DORNBUSCH

Massachusetts Institute of Technology

ALEJANDRO WERNER

Massachusetts Institute of Technology

\title{
Mexico: Stabilization, Reform, and No Growth
}

IN THE SECOND HALF of the 1980s, after strenuous efforts, Mexico was coming to be viewed as a showcase of successful stabilization and economic reform, institutional stability, and financial predictability. Mexico was becoming what Chile already had become and what all of Latin America hoped to be. But the Chiapas uprising, the assassination of presidential candidate Luis Donaldo Colosio, the ensuing muddle about his succession, and the sheer fact of an election year have raised doubts about Mexico's ability to achieve lasting stability. By April 1994, the sharp upturn in interest rates, arising from speculative attacks on the peso, suggested that a far too optimistic view may have been taken of Mexico's future. The Mexican economy had come to a virtual standstill. Per capita income is now far below what it was in 1980, as shown in figure 1, and from 1992 to 1993 it fell by 1.2 percent. Moreover, any positive growth that may occur, in 1994, will have been fueled by fiscal expansion not by strength in the real economy.

This paper argues that Mexico suffers from a failure to accompany the stabilization of inflation, shown in figure 2 , and the impressive array of economic reforms with not only true political reform but also true economic progress. The stabilization strategy has led to an overvaluation of the exchange rate, a precarious financial situation, and a lack of growth. Real interest rates paid by firms continue to be very high, nonperforming loans have been increasing, and the current account deficit stands at more than $\$ 20$ billion.

Arguably, the lack of growth may reflect the costs of transition, as the massive restructuring causes expansion in some industries and contrac- 
Figure 1. Per Capita GDP in Mexico, 1970-93

Index, $1972=100$

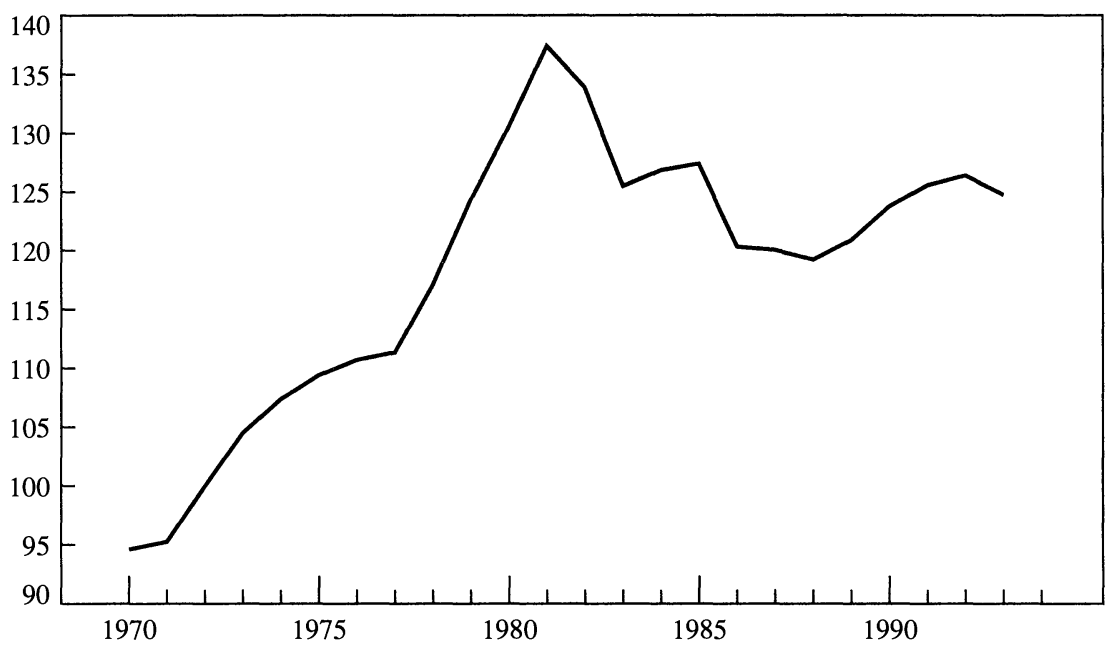

Source: Authors' calculations based on International Financial Statistics.

Figure 2. Mexican Consumer Price Inflation, 1980-93

Percent ${ }^{\mathrm{a}}$

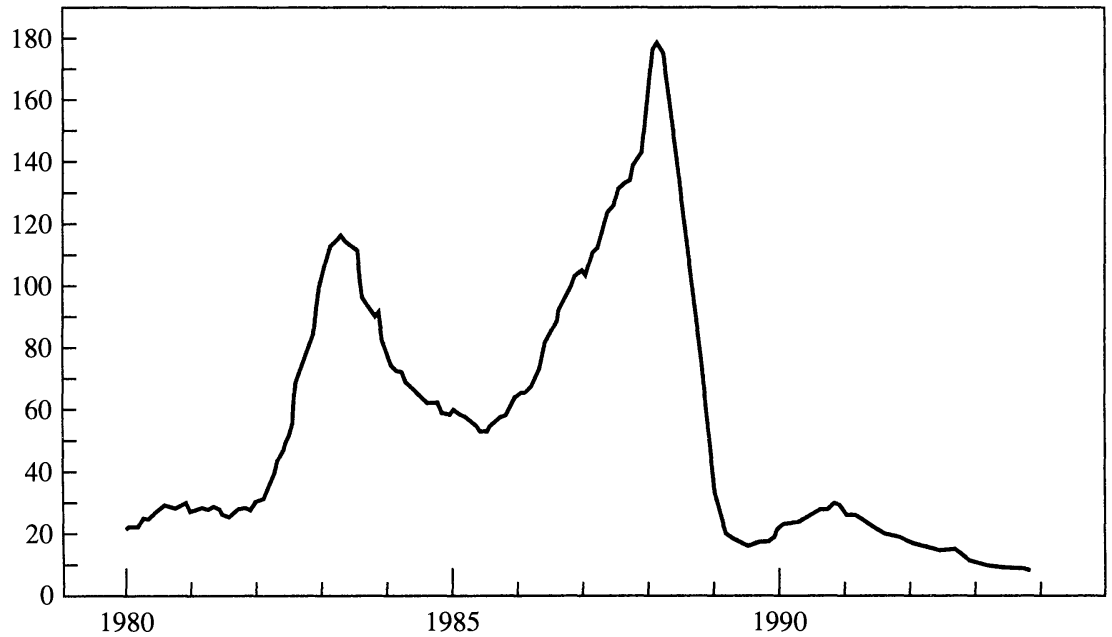

Source: Authors' calculations based on Banco de México, Indicadores Económicos, various issues.

a. Inflation rate measured as the change in the current month's consumer price level over the level 12 months earlier. 
tion in others, with the balance expected to shift soon toward expansion as the rewards of reform cumulate into sustained high growth. The more pessimistic view, however, is that just as in Chile in the late 1970s positive, sustainable growth will come only after the overvaluation is corrected.

Of course, whether an overvaluation exists is controversial. Until very recently, the level of interest rates and capital inflows did not suggest a problem at all. During the past few years the country has been flooded with capital inflows, and the passage of the North American Free Trade Agreement (NAFTA) has only bolstered that trend. This avalanche of capital has strengthened the currency in real terms-which is the expected effect of an inward transfer. In other words, if a country borrows to invest, real appreciation accompanies the high level of resource absorption, more so if deep reform opens up large, lasting opportunities. The credit rating has also been improving steadily, with the cost of capital falling by 150 basis points since the passage of NAFTA (September 1993 to December 1993).

This positive take on recent developments is articulated by Mexican policymakers whenever they are challenged about the economy's direction. Guillermo Ortiz, for example, argues,

It is true that the Mexican currency has appreciated, but such a fact is far from implying a strong devaluation of the currency. That depends on the equilibrium of the real exchange rate, which is difficult to calculate, adding to the fact that the peso had undergone a strong devaluation before the current stabilization effort started, which probably made it undervalued. . . . the appreciation process is a natural, and not necessarily negative, consequence of the reform process in Mexico. ${ }^{1}$

Less sanguine observers argue that the financial flows may be fragile, however. The flows are financing not only investment but also a high level of consumption and intermediate goods imports, with the large external deficit dampening demand for domestic goods. For full employment to occur, then, crowding-in is required (through an increase in the demand for domestic production). According to this argument, trade liberalization, which was an important part of recent reform, should have been accompanied by real depreciation not appreciation. To a large extent, we agree real depreciation is needed to improve the long-term economic prospects of Mexico and secure the benefits of economic reform. 
Table 1. Long-Run Economic Performance of Mexico, 1955-93

Percent per year

\begin{tabular}{ccc}
\hline Period & $\begin{array}{c}\text { Real per } \\
\text { capita GDP }\end{array}$ & $\begin{array}{c}\text { Consumer } \\
\text { price } \\
\text { inflation }\end{array}$ \\
\hline $1955-72$ & 3.1 & 3.9 \\
$1972-81$ & 3.6 & 20.6 \\
$1981-88$ & -2.0 & 86.2 \\
$1988-92$ & 1.5 & 21.1 \\
1993 & -1.2 & 9.7
\end{tabular}

Source: Authors' calculations based on International Financial Statistics and unpublished data from Instituto Nacional de Estadística, Geografía, e Información (INEGI).

a. Year average over previous year's average.

\section{Historical Background}

From the mid-1950s to the 1970s, Mexico was a paragon of financial stability and growth. The exchange rate against the dollar was fixed; convertibility was unrestricted; inflation was moderate; and growth of real per capita income was high. Table 1 traces the long-run growth and inflation performance of the Mexican economy.

The stability ended with the oil price increases of the 1970 s because of fiscal extravagance resulting from dramatic increases in revenue from oil exports. With added room in the budget, policies became highly expansionary, the currency became overvalued, government borrowing increased, and capital flight began. A huge increase in government debt and the collapse of the financial system, as well as the exchange rate, soon followed. Mexico became insolvent in 1982-the first of the debtor countries to do so-and shifted to a regime of debt restructuring, which culminated in the 1990 Brady plan agreements brokered by then-U.S. Treasury Secretary Nicholas Brady. As a result of the Brady plan and the reforms that accompanied it, voluntary lending returned earlier than expected and in large amounts. ${ }^{2}$ We detail the key areas of reform below.

\section{Return to Voluntary Lending}

In the period leading up to 1982, Mexico accumulated an external debt amounting to 49 percent of gross domestic product. The accumula-

2. See Aspe (1993) for a comprehensive account of the reforms. 
Table 2. Mexican Debt and Transfers, 1982 and 1992

Percent of GDP, except as noted

\begin{tabular}{lrr}
\hline \multicolumn{1}{c}{ Indicator } & 1982 & \multicolumn{1}{c}{1992} \\
\hline External debt & 49.0 & 32.0 \\
Resource transfer $^{\mathrm{a}}$ & 5.4 & -5.3 \\
Reserves $^{\mathrm{b}}$ & 1.8 & 19.3 \\
\hline
\end{tabular}

Sources: Authors' calculations based on data from Banco de México (1993); Aspe (1993); and Salinas de Gortari (1993).

a. Noninterest current account surplus as percent of GDP.

b. Billions of U.S. dollars at end of year.

tion was mostly due to large current account imbalances. But, in addition, the growing currency overvaluation and financial turmoil-including exchange control and bank nationalizations-meant that capital flight became an important additional factor in running up the external debt. The picture was completed by extremely high U.S. interest rates, which led to large debt service financed by more borrowing.

However, just like Germany during the Weimar republic, Mexico never paid much of what looked, in 1985, like a crushing debt service burden. Early involuntary bank lending and credits from multilateral institutions reduced the crisis. And since 1989, Mexico has had access to international borrowing-in fact, foreign investors have eagerly sought Mexican government debt in pesos and dollars, and Mexican firms have borrowed in the world market. Mexico's external position is described in table 2 .

As mentioned above, the turning point in Mexican external financing was the Brady plan. Until that time, multilateral institutions and the U.S. Treasury held the firm view that debt forgiveness would have highly adverse consequences for debtors and creditors alike. Many felt that banks were in a poor position to recognize the capital losses and that debtors' creditworthiness would be tarnished for a long time if they did not meet their obligations. But the Brady plan was able to remove the debt issue from the agenda and shift attention to reform and modernization. This shift, in Mexico and elsewhere in Latin America, broke the ground for Mexico's return to world capital markets and for direct investment in the country.

The Brady plan improved Mexico's ability to service its external debt by reducing the interest and principal payments it had to make. ${ }^{3}$ The

3. See Claessens, Oks, and van Wijnbergen (1994). 
Table 3. Net Capital Inflows into Mexico, 1989-92

Billions of U.S. dollars

\begin{tabular}{lrrrr}
\hline $\begin{array}{c}\text { Type of } \\
\text { investment }\end{array}$ & 1989 & 1990 & 1991 & 1992 \\
\hline Portfolio & -1.7 & 5.9 & 19.6 & 21.1 \\
Direct & 2.6 & 2.5 & 4.7 & 5.4 \\
\hline
\end{tabular}

Source: International Financial Statistics.

yield spread in the international market between Mexican public debt and industrial country debt of comparable maturity fell from 820 basis points in 1989 to about 200 basis points in the first half of $1993 .{ }^{4}$ The improvement cannot be fully attributed to the debt reduction scheme, however. Some credit also goes to the macroeconomic reforms undertaken by Mexico, as well as the large reduction in world interest rates, which alleviated the debt service burden. The trends in voluntary capital flows are shown in table 3. In 1988, capital was still flowing out of Mexico; in 1989 , inflows barely reached $\$ 0.9$ billion. But by 1992 , two years after the Brady plan, they amounted to almost $\$ 26.5$ billion; and in just the first three quarters of 1993, capital inflows totaled $\$ 22$ billion.

Improving prospects in the private sector along with an increase in the worldwide flow of capital toward emerging markets were other important causes of rising capital inflows, as private borrowing and equity financing began to replace government borrowing in the capital markets. ${ }^{5}$ The resulting boom in the stock market was both an effect and a cause of the inflows-the flows helped boost the market, which attracted still more capital. The stock market rose 125 percent in 1991, about 25 percent in 1992, and almost 50 percent in 1993. The capital inflows also led to an accumulation of reserves and a steady decline in interest rates.

Thus far, direct investment has been relatively small, but it is expected to increase with NAFTA's passage. One private forecast, for example, envisages a near-doubling of the rate of private direct investment in $1994 .{ }^{6}$ There is no reason to believe that with a stable and competitive economy Mexico is not capable of attracting a very substantial inflow of

4. See IMF (1993, p. 64).

5. See Calvo, Leiderman, and Reinhart (1993a, 1993b).

6. See Centro de Análisis e Investigación Económica (1994, p. 19). 
capital. By way of comparison, between 1982 and 1990, after Spain's entry into the Common Market, direct foreign investment in that country increased from 0.8 percent to 2.1 percent of GDP. ${ }^{7}$

Waves of excitement in supplying developing countries with capital are not unprecedented. The historical record can lend some perspective to the present upswing in capital inflows. Taussig describes the usual sequence of events,

The loans from the creditor country . . . begin with modest amounts and proceed crescendo. They are likely to be made in exceptionally larger amounts toward the culminating stage of a period of activity and speculative upswing, and during that stage become larger from month to month so long as the upswing continues. With the advent of crisis, they are at once cut down sharply, even cease entirely. The interest payments on the old loans thereupon are no longer offset by any new loans; they become instantly a net charge to be met by the borrowing country. A sudden reversal takes place in the debtor country's international balance sheet; it feels the consequences abruptly, in an immediate need of increased remittances to the creditor country, in a strain on its banks, high rates of discount, falling prices. And this train of events may ensue not only once. . . .

Taussig's view understates the potential trouble in Mexico. The foreign portfolio capital invested in the Mexican money market, as well as investments in stocks, is highly liquid. Moreover, there is not only scheduled debt service but also a very large trade deficit that is financed by borrowing abroad.

Perhaps Mexico will prove Taussig wrong, however, and the usual pattern of excess lending and subsequent crisis is not relevant. But for this time to be different, there would have to be fundamental and irreversible change in the debtor country to warrant the sustained large inflows. Today, the possibility of such change is much greater than it has ever been before.

\section{Budget Correction and Privatization}

Budget consolidation was a central part of Mexican stabilization and reform. Here, Mexico pursued three objectives: a major cut in government spending; tax reform to increase the tax base, efficiency, and compliance; and privatization of state-owned enterprises. On the spending side, investment expenditures were cut by 5 percent of GDP. On the rev-

7. Calculated using the data reported in International Financial Statistics.

8. Taussig (1927, p. 130). 
Table 4. Mexican Budget and Debt, 1982-92

Percent of GDP

\begin{tabular}{lrrr}
\hline Indicator & \multicolumn{1}{c}{1982} & 1983 & \multicolumn{1}{c}{$1992^{\mathrm{a}}$} \\
\hline Budget surplus & & & \\
$\quad$ Total $^{\mathrm{b}}$ & -16.9 & -8.6 & 0.5 \\
Operationalc $^{\mathrm{c}}$ & -5.5 & 0.4 & 3.6 \\
Primaryd $^{\mathrm{d}}$ & -7.3 & 4.2 & 5.6 \\
Taxes & 8.7 & 8.4 & 12.2 \\
Debt & & & \\
$\quad$ Domestic & 15.5 & 16.5 & 10.1 \\
$\quad$ Foreign & 35.8 & 43.7 & 16.4 \\
\hline
\end{tabular}

Source: Authors' calculations based on Banco de México (1993).

a. Numbers exclude revenues from privatization.

b. Public sector borrowing requirements.

c. Public sector borrowing requirements adjusted by the inflationary component of interest payments on domestic debt.

d. Public sector borrowing requirements plus interest payments on government debt.

Figure 3. Mexican Public Debt, 1980-92

Percent of GDP

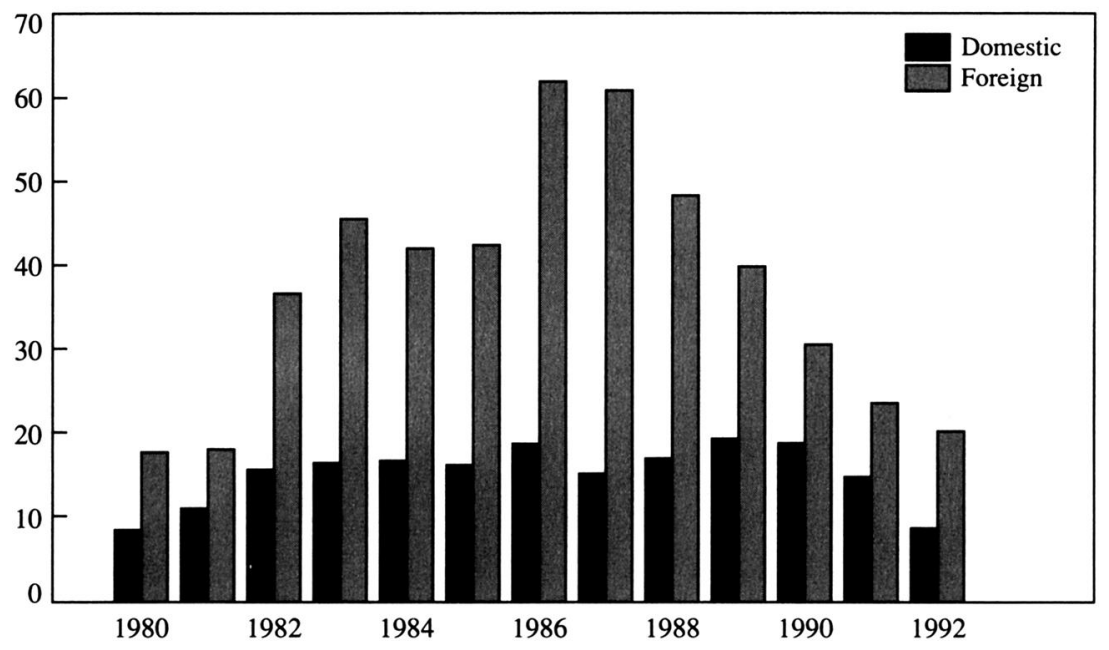

Source: Authors' calculations based on Banco de México (1993).

enue side, during 1982-92, the tax yield was raised by 4 percent of GDP even while marginal tax rates were reduced. Table 4 reports some general trends in the budget.

This extraordinary reduction in the operational budget deficit- 9 percent of GDP, or the equivalent of three Gramm-Rudman cuts, as many Mexicans put it-set the stage for Mexico's strategy of disinflation, im- 
Table 5. State Enterprises in Mexico, 1982-92

\begin{tabular}{lrrr}
\hline \multicolumn{1}{c}{ Indicator } & 1982 & \multicolumn{1}{c}{1986} & \multicolumn{1}{c}{1992} \\
\hline Number of enterprises & 1,155 & 737 & 217 \\
Employment $^{\mathrm{a}}$ & 886.2 & $1,028.0$ & 530.6 \\
\hline
\end{tabular}

Sources: Informe Hacendario, October-December (1993, p. 27); and unpublished government data from INEGI. a. Thousands.

proved confidence in the currency, and ultimately lowered interest rates. With primary surpluses averaging 5.3 percent of GDP over the 1983-92 period, the debt-to-GDP ratio declined, as shown in figure 3, even though growth was very slow or negative.

Privatization was a key part of the public finance reforms. The large government deficits could be most effectively controlled by either selling off firms or simply closing them. If a firm were unprofitable, closing it cut the drain on government resources. If a firm were potentially profitable, revenues from its sale could help improve public finance by reducing the cost of financing the public debt. Table 5 describes the position of state enterprises in Mexico over the past decade.

Privatization also played a role in drawing foreign attention to investment opportunities in Mexico and fueling the external financing of Mexican reform. It acted as a galvanizing force at a time when low interest rates in the United States had created a willing group of investors.

\section{Trade Reform}

Among the specific macroeconomic reforms undertaken by Mexico was trade reform. Table 6 shows the trade liberalization that occurred in the 1980s. Average tariff rates declined, as did the dispersion of rates.

The tariff reductions particularly apply to consumer goods. In this

Table 6. Tariff Levels in Mexico, 1982-92

Percent

\begin{tabular}{lrrr}
\hline \multicolumn{1}{c}{ Tariff statistic } & 1982 & 1986 & 1992 \\
\hline Average tariff & 27.0 & 22.6 & 13.1 \\
Trade-weighted average & 16.4 & 13.1 & 11.1 \\
Tariff dispersion & 24.8 & 14.1 & 4.5 \\
Import quota cover rate $^{\mathrm{a}}$ & 100.0 & 28.0 & 11.0 \\
\hline
\end{tabular}

Source: General Agreement on Tariffs and Trade (1993, vol. 1, p. 74, and vol. 2, p. 51).

a. Percentage of total value of imports subject to quantitative restrictions. 
category, the average tariff declined from 60 percent in 1983-84 to less than 20 percent in 1992 . For intermediate and capital goods, the initial level was about 20 percent and hence the liberalization was more moderate. Import quotas, which were pervasive in the 1980 s, are now nearly gone. ${ }^{9}$ Far bolder than these measures will be the complete liberalization of trade in goods and services to occur in North America over the next 15 years in accordance with NAFTA.

\section{Factors behind the Real Exchange Rate Appreciation}

We now turn to alternative interpretations of the real exchange rate appreciation in Mexico. One view emphasizes the prosperity and new opportunities brought about by the appreciation. The other recognizes the improvements but argues that the manner in which the stabilization was accomplished sowed the seeds of an overvaluation that is becoming a source of speculative instability. As we argue below, the interaction of two major policy steps bears much of the responsibility for the overvaluation: nominal exchange rate stabilization and incomes policy.

As mentioned earlier, Mexico has experienced a huge real appreciation in its exchange rate over the past few years. The dramatic trade opening of the 1980s has thus been accompanied by a rise in the relative price of Mexican goods, and a large external deficit has emerged. Real interest rates have declined over the past few years but remain exceptionally high. GDP growth has been negligible. The combined evidence suggests that demand has shifted to foreign goods and that the growthreducing effect of real appreciation has been aggravated by a high real cost of credit.

Figures 4-6 show Mexico's trade balance, current account, and import penetration. They leave no doubt of a major deterioration since the mid-1980s. The current account deficit has risen to almost 7 percent of GDP, a very high number for a developing country. And the external deterioration would have been even worse without the strong export growth of recent years. In the 1985-92 period, exports increased by about 75 percent, as imports tripled. ${ }^{10}$ As a result of this imbalance, lack of financing is becoming a real issue. The trade liberalization previously

9. See General Agreement on Tariffs and Trade (1993, vol. 1, pp. 74-75, and vol. 2, pp. 50-51).

10. More exactly, imports increased by 238 percent and total exports by 73 percent. 
Figure 4. Mexican Trade Balance, 1975-93

Billions of U.S. dollars ${ }^{a}$

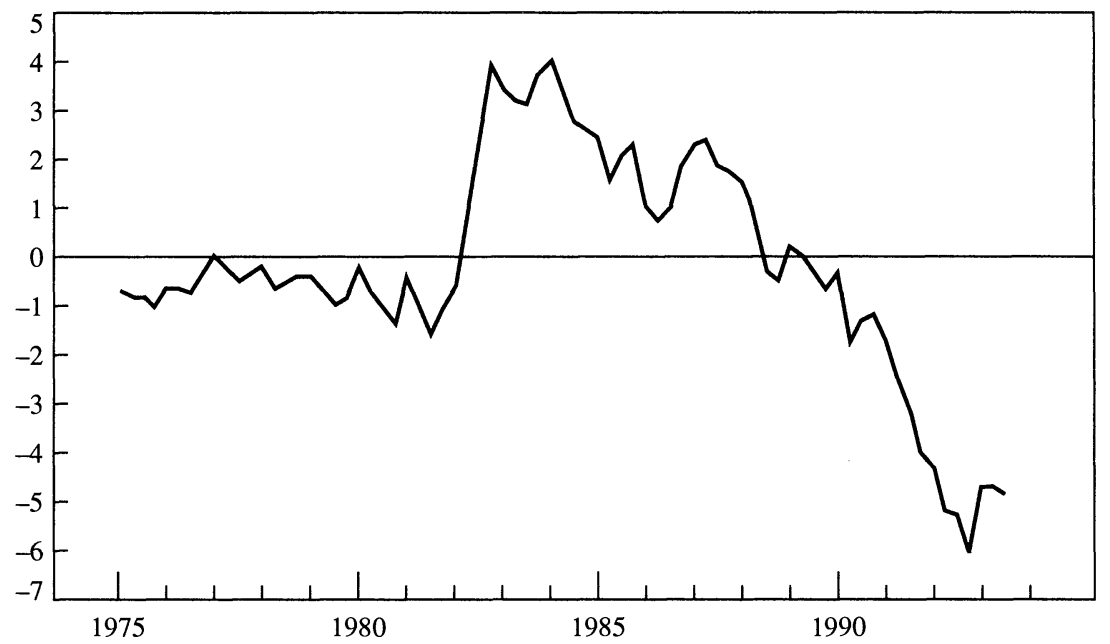

Source: Banco de México, Indicadores Económicos, various issues. a. The amount plotted is the figure for each quarter.

Figure 5. Mexican Current Account, 1970-93

Billions of U.S. dollars

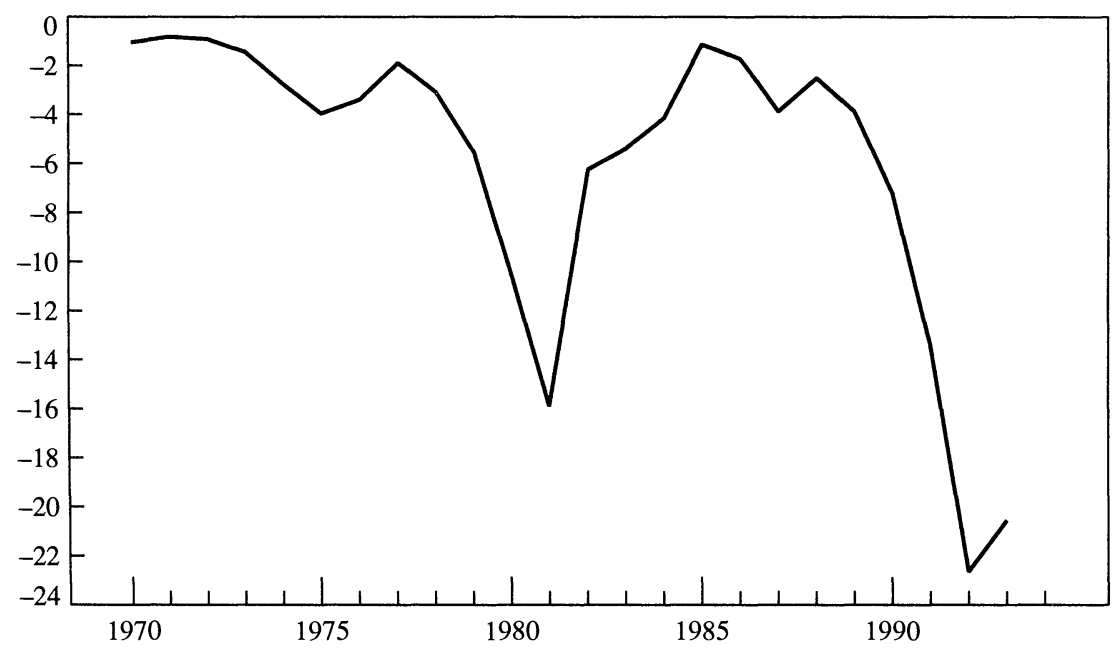

Source: Authors' calculations based on Banco de México, Indicadores Económicos, various issues. 
Figure 6. Imports as a Percent of Mexican GDP, 1970-92

Percent

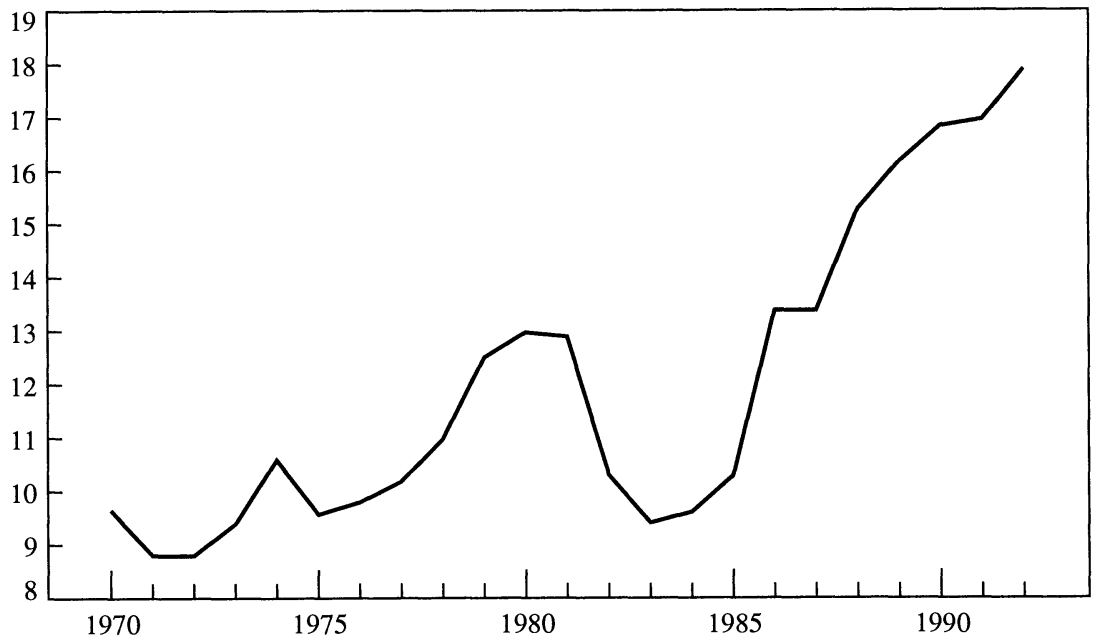

Source: Banco de México, Indicadores Económicos, various issues.

Figure 7. Mexico-U.S. Relative Price Levels, 1970-93

Index, $1985=100^{\mathrm{a}}$

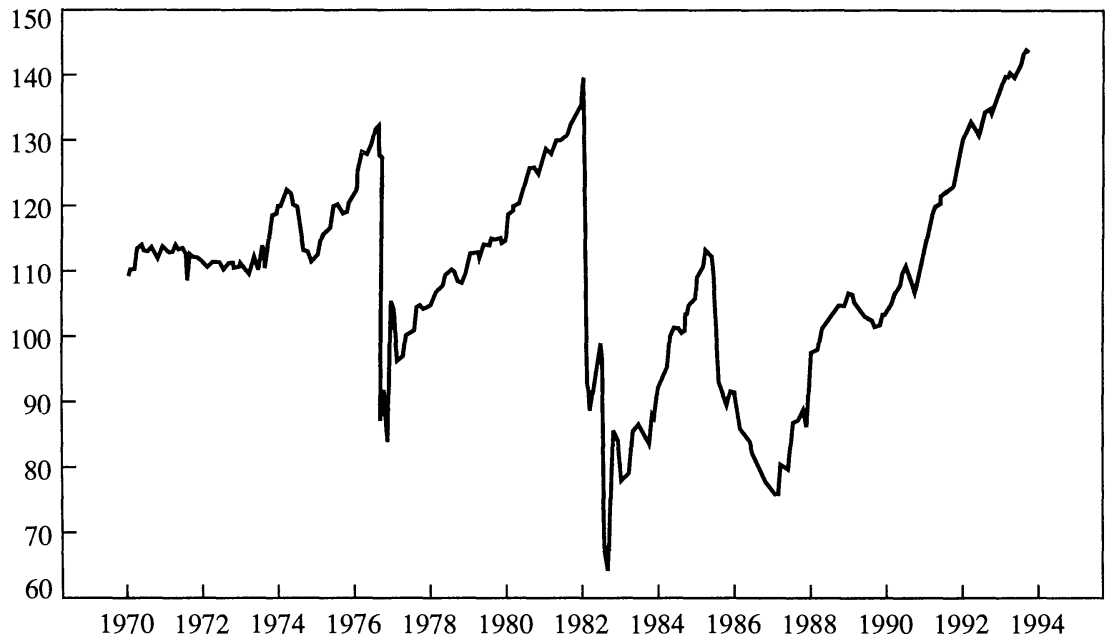

Source: Authors' calculations based on International Financial Statistics.

a. The index is constructed using wholesale price data from Mexico and the United States, denominated in dollars. 
Table 7. Competitiveness Measures for Mexico, 1989-93

Units as indicated

\begin{tabular}{lrrrr}
\hline \multicolumn{1}{c}{ Measure } & 1989 & 1990 & 1992 & 1993 \\
\hline Wages in dollars $^{\mathrm{a}}$ & 1.58 & 1.64 & 2.35 & 2.65 \\
J.P. Morgan index $^{\mathrm{b}}$ & 108 & 100 & 108 & 117 \\
Banco de México index $^{\mathrm{c}}$ & 88 & 92 & 109 & 112 \\
\hline
\end{tabular}

Sources: Authors' calculations based on unpublished data from the U.S. Bureau of Labor Statistics; Banco de México (1993); Morgan Guaranty Trust Company (various issues).

a. Hourly compensation in manufacturing in dollars.

b. J.P. Morgan multilateral real effective exchange rate index in nonfood manufacturing, $1990=100$.

c. Real exchange rate index based on the unit labor costs in manufacturing, $1985=100$.

discussed is one reason for the large increase in imports and import penetration-strong growth clearly is not-but real appreciation can be held accountable for the trade deterioration, too. It has reinforced the trade pattern by making imports cheaper and restricting export expansion.

There are a number of measures of the real exchange rate. We show the least elaborate one in figure 7: producer prices in Mexico relative to those in the United States, as measured in a common currency. The figure makes it apparent that since 1987 the real exchange rate has steadily appreciated to today's historic high. The rate is even higher than at its pinnacle before the currency collapse in 1982. Of course, there is no good benchmark date against which to judge the current levels, and certainly a moment of maximum distress, such as 1982 or 1986, is not an appropriate starting point. On the other hand, a real exchange rate that is higher than ever before is suspicious, even when major reforms and access to capital justify some real appreciation.

Table 7 shows several real exchange rate measures. Even if the U.S. comparison were inconclusive, each of these numbers tells a similar story. By all measures, prices in Mexico, on a dollar basis, have risen relative to those in the rest of the world. Moreover, except for the minidevaluation at the beginning of 1994, the process continues: the J.P. Morgan index reached 121.7 in January 1994, compared with its 1990 (base year) level of 100 .

Other aspects of the domestic economy are also relevant here. Growth has been slow and came to a halt in 1993. Figure 8 shows that (formal) employment has been falling and that industrial production since 1992 is at best flat. The evidence on production confirms the evidence gleaned from prices: something is awry in the Mexican economy. 
Figure 8. Industrial Production and Employment in Mexico, 1988-93

Index, $1980=100^{\mathrm{a}}$

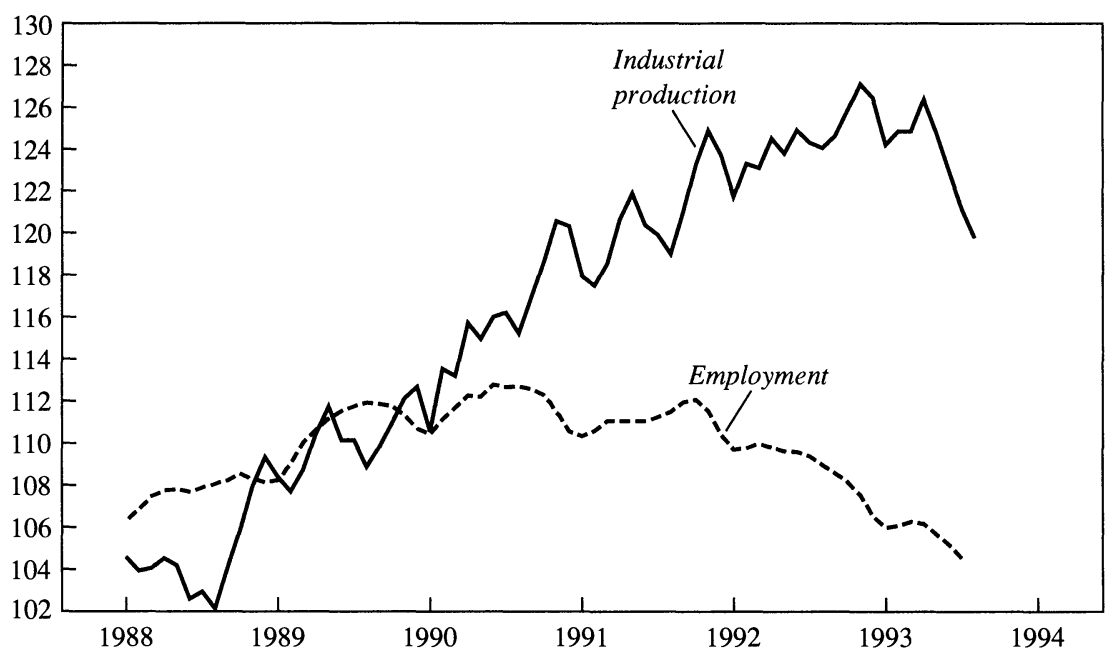

Source: Authors' calculations based on the industrial production index from International Financial Statistics and employment figures from Data Resources, Inc.

a. Indexes are constructed using three-month moving averages of the data.

Two explanations for this evidence are offered by the more optimistic observers. First, it is asserted that reform, modernization, and the return to world capital markets (reinforced by the institutionalization that NAFTA is bringing) have changed the equilibrium prices of labor and assets. And the fact that prices have increased so much is not surprising, since Mexico has come from the deep troughs of 1982 and 1986 to very high peaks. This view stresses that Mexican reforms have been spectacular, lasting, and the envy of any reform economy. In other words, these observers argue that real appreciation should not be confused with overvaluation.

A related but more moderate view concedes that Mexico has a growth problem but that it is only transitory. Some firms are contracting as they adjust to the new and forward-looking equilibrium real exchange rate, while other firms are expanding to meet new opportunities. Increasingly, in their view, the expansion will come to dominate the contraction. 


\section{Theoretical Approaches to the Exchange Rate Problem}

We now examine these different assertions using two theoretical approaches to the exchange rate question. One clarifies what to expect in an equilibrium model from the various reforms, identifying in particular the effects of liberalizing trade and capital flows on the real exchange rate. The other model looks at the mechanics of an incomes policybased stabilization to show that the overvaluation could have been predicted.

\section{Equilibrium Hypothesis}

The first model focuses on the interaction of capital, goods, and labor during the process of trade liberalization, domestic fiscal tightening, and improving the access to external capital. Specifically, we are interested in the predictions of the equilibrium model regarding resource allocation, asset prices, and the real exchange rate. We review the Mexican reforms, one at a time, in terms of this model.

We assume that capital is used to produce tradables. Nontradables, or home goods, by contrast, are produced with labor alone. Labor is mobile across all sectors. In the tradables market, firms produce at given world prices with capital and labor. Production functions are neoclassical. Thus, labor demand in the traded goods sector depends on the given capital stock and the wage in terms of dollars. An increase in the product wage reduces the demand for labor in the traded goods sector at a given capital stock.

Consider now the home goods market. To start, assume that all disposable income from labor is spent and all income from capital is saved and invested at home. There is also government spending in the amount $G$, which is initially financed by borrowing abroad. Demand for home goods is a function of the relative price of exports and imports in terms of home goods. We assume that expenditure shares are constant. We also assume a given unit labor requirement. For simplicity, it is set at unity.

The rate of investment in the economy depends on the profitability of installing capital. Installation of new capital uses imported machinery with an increasing marginal cost. The higher the price of installed capital 
in dollars, the higher is the rate of gross investment. Net investment is gross investment less the given rate of depreciation:

$$
\dot{K}=I(q)-d K,
$$

where $\dot{K}$ is the increase in the capital stock, $K$ is the capital stock, $I$ is gross investment, $d$ is the rate of depreciation of the capital stock, and (Tobin's) $q$ is the price of installed capital in dollars.

Wages in dollars, $w$, are determined in the labor market that is in equilibrium when sectoral labor demands equal the available labor supply. Accordingly, the labor market yields an equilibrium wage as a function of the capital stock, the level of government spending, and the income tax rate:

$$
w=w(\stackrel{+}{K}, \stackrel{+}{G}, \bar{t}),
$$

where $t$ is the income tax rate.

Other things equal, equilibrium wages in dollars are higher, the higher is the economy's aggregate capital stock or the higher is government spending. A higher income tax rate reduces the demand for home goods and thus, other things equal, reduces wages.

The model is closed by specifying either access to the capital market or the financing of investment. We first consider the case where there is no access to the international capital market. All investment is financed at home out of income from capital. Income from capital increases with the capital stock but declines as the wage in dollars rises, because the return to a unit of capital, $R(w)$, is declining in $w$ :

$$
q I(q)=K R(w) .
$$

The model is summarized in figure 9. Along the IS schedule, the labor market clears, and saving is equal to investment. The schedule is normally upward sloping to reflect the assumption that a rise in the capital stock raises total profits. Along the $\dot{K}=0$ schedule, the capital stock is constant. The economy's steady state is point $\mathrm{A}$, where saving is equal to investment and the capital stock is stationary.

Consider now the effect of budget consolidation through higher tax rates or lower government spending. Reduced labor demand arising in the home goods market will lower the equilibrium real wage. For a given capital stock, the fall in dollar wages raises profits. Thus, the IS curve 
Figure 9. Capital Accumulation in a Financially Closed Economy

Price of

installed

capital, $q$

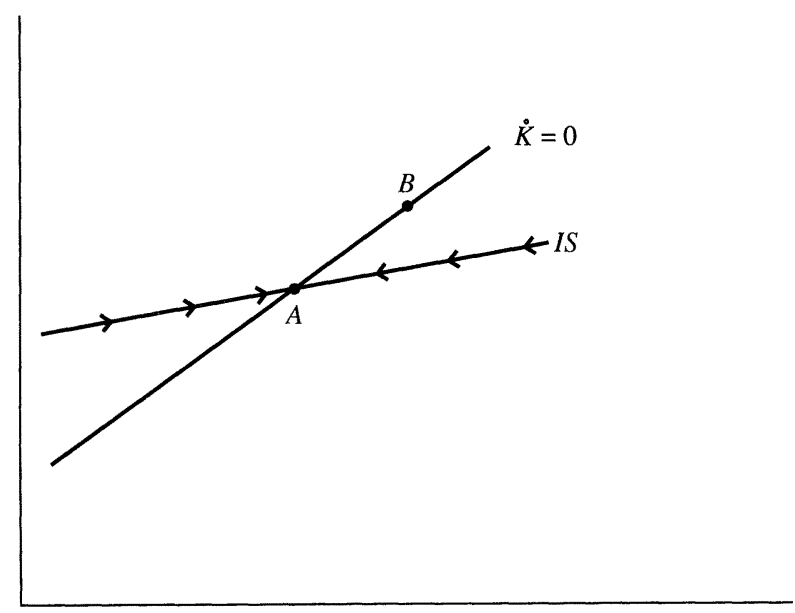

Capital stock, $K$

shifts upward to IS' (not shown). There are immediate increases in profits, the real price of capital, and the equilibrium rate of investment. Over time the economy moves to point B. Capital will have been accumulated and the fall in the real wage will have been offset, at least partially, by the increased capital stock. The traded goods sector expands as the shift toward a balanced budget involves a cut in demand and a reallocation of resources to the traded goods sector.

As for the real exchange rate, one must look at the wage in dollars. This model predicts that budget cuts will lead to real depreciation-a fall in the wage in dollars-in the short run. Later, as capital accumulates there is some real appreciation.

Consider next the case where the economy opens up financially. Specifically, let the country in the model have access to capital at the yield $i^{*}$ in dollars, which is the New York prime rate plus a risk premium. The arbitrage equation representing the capital market equilibrium is

$$
\dot{q} / q=i^{*}-R(w) / q .
$$

Figure 10 shows the initial equilibrium at point $\mathrm{A}$. The immediate effect of the financial reform (assuming $i^{*}<d$ ) is a boom in asset prices, mov- 
Figure 10. Capital Accumulation in a Financially Open Economy

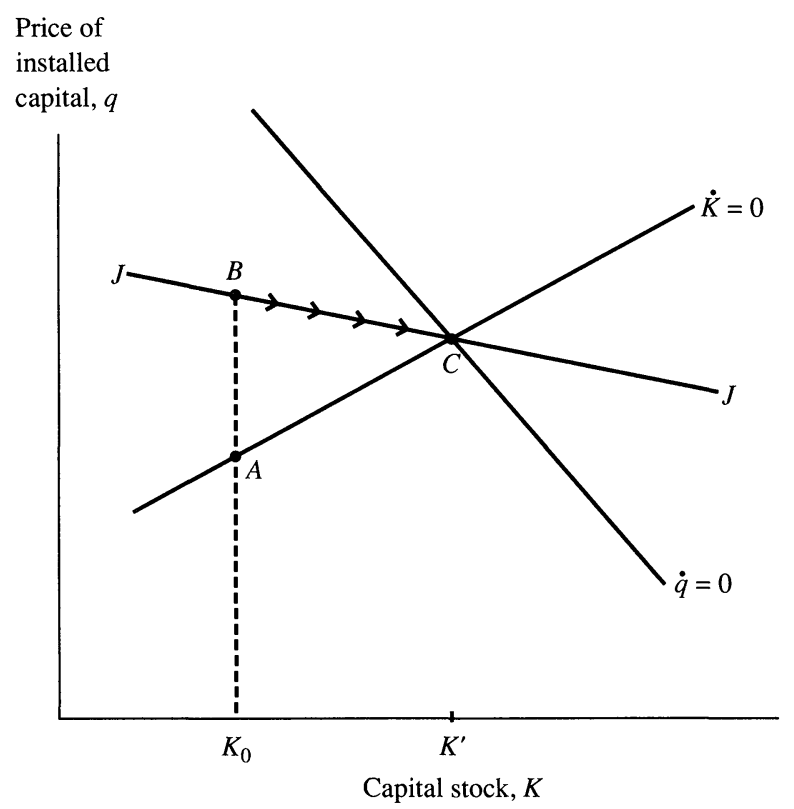

ing the economy from point $\mathrm{A}$ to $\mathrm{B}$. Then the economy moves along the stable trajectory JJ from point B to C. The high real price of capital immediately encourages a higher rate of capital formation. Over time, as capital accumulates, real wages rise or the real exchange rate appreciates. The traded goods sector expands by becoming more capital intensive. The expansion is made possible by the high valuation of capital and the resulting capital accumulation.

The model highlights that greater access to world capital markets brings about equilibrium real appreciation. It also improves welfare for workers while rewarding owners of existing capital. Everybody wins, even the government, since the tax base and hence tax revenues expand.

The process of opening up the capital account or gaining access to world capital markets is reinforced when the political risk premium declines. This corresponds to a reduction in the cost of capital, $i^{*}$, and an upward shift in the trajectory JJ (not shown). Stock prices rise and investment booms. Finally, real wages rise and the tax base expands-resulting in prosperity for all.

Access to the capital market also affects consumer behavior. Spe- 
cifically, domestic financial repression and credit rationing may decline, a process that could be fostered by an international financial opening. Availability of consumer credit then raises spending, part of which falls on home goods. Wages in dollars rise, and this effect tends to reduce asset prices (in the tradable goods sector) and reduce capital formation. Financial opening is therefore a mixed issue. Its effects on capital formation depend on whether there is significant financing for consumers as opposed to firms. ${ }^{11}$

Next consider the effects of trade liberalization. Suppose specifically that a group of imported consumer goods, previously prohibited, becomes available. We represent this as a fall in the share of nontraded goods in total spending. As the demand for home goods declines, the equilibrium wage in dollars falls. The increased profitability of capital in the traded goods sector boosts the stock market. Over time, capital accumulates and real wages recover. To maintain full employment, trade liberalization unambiguously requires a real depreciation or a fall in the dollar wage.

Finally, measures that increase efficiency also affect the equilibrium model. An increase in total factor productivity increases labor demand and raises the equilibrium relative wage. Even so, profitability rises and the real price of capital increases accordingly. Capital formation expands, raising real wages.

\section{Overvaluation Hypothesis}

The overvaluation hypothesis views the real appreciation of the exchange rate as the outcome of an inflation stabilization using incomes policy and exchange rate targeting. In Mexico, such policies were central to bringing down inflation from its peak of nearly 200 percent (figure 2).

Incomes policy is practiced in a formal and ceremonious agreement called the pacto. The parties are the government-friendly unions with their octogenarian boss Don Fidel Velasquez, representatives of the business community, and the government. Labor agrees to limit wage inflation; business agrees to limit price increases; and the government contributes with commitments on public sector prices and the exchange rate. The agreements initially ran for 2 months and have been extended

11. This point is made by Japelli and Pagano (1994). 
Table 8. Inflation and Depreciation in Mexico, 1987-93

Percent per year

\begin{tabular}{lccccr}
\hline Year & $\begin{array}{c}\text { Producer } \\
\text { price } \\
\text { index }^{\mathrm{a}}\end{array}$ & $\begin{array}{c}\text { Consumer } \\
\text { price }_{\text {index }}\end{array}$ & $\begin{array}{c}\text { GDP } \\
\text { deflator }\end{array}$ & $\begin{array}{c}\text { Wage } \\
\text { inflation }^{\mathrm{b}}\end{array}$ & $\begin{array}{c}\text { Exchange } \\
\text { rate }^{\mathrm{c}}\end{array}$ \\
\hline 1987 & 145.3 & 131.8 & 139.6 & 128.9 & 120.4 \\
1988 & 99.3 & 114.2 & 99.4 & 109.7 & 62.9 \\
1989 & 12.8 & 20.0 & 25.9 & 30.8 & 8.5 \\
1990 & 22.7 & 26.7 & 29.5 & 30.6 & 14.3 \\
1991 & 19.1 & 22.7 & 21.6 & 28.4 & 6.2 \\
1992 & 12.0 & 15.5 & 16.2 & 26.6 & 2.6 \\
1993 & 6.6 & 9.8 & 11.0 & $16.5^{\mathrm{d}}$ & 0.0 \\
\hline
\end{tabular}

Sources: Banco de México (1993); Banco de México, Indicadores Económicos, various issues; and unpublished data from the Mexican Finance Ministry.

a. Year average over previous year's average.

b. Nominal average earnings in manufacturing.

c. Pesos per dollar.

d. Measured from August to August.

to 6 and 12 months. They have been followed by the government and renewed regularly. In appendix A, we report the terms of the pacto agreements of the 1987-93 period.

At the outset, the pacto contained price controls for a basket of essential consumer goods. Increasingly, the use of formal controls has receded and given way to a broad understanding of the room for price increases, specific wage targets, and discussions of productivity-based wage policies. The exchange rate commitment by the government continues to be central. Mexico has taken a decidedly corporatist approach to prices and the labor market. The government because of its pervasive, unrestricted powers can make agreements stick.

Trade liberalization was another feature of the disinflation strategy. Since domestic markets in Mexico were highly oligopolistic and controls might risk shortages, liberalization was used to enforce better price discipline and alleviate potential shortages.

The process of disinflation is shown in table 8 . As one can see, during 1987-93, wholesale prices fell more rapidly than consumer prices. The reason is that the budget correction meant the withdrawal of various subsidies that enter the consumer price index (CPI) but not the producer price index (PPI). The most striking point, though, is the discrepancy between PPI inflation and exchange rate depreciation brought out in figure 11 . The government systematically used underdepreciation or de- 
Figure 11. Mexican Producer Prices and the Exchange Rate, 1988-94 Index, 1988:1 $=100$

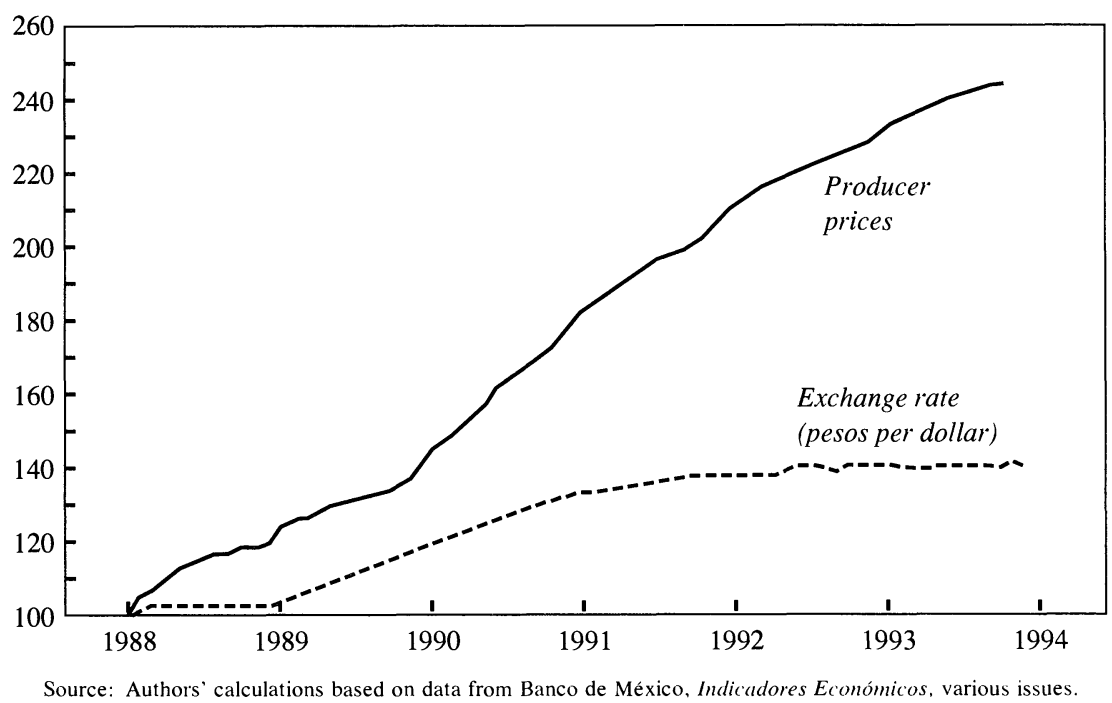

parture from a purchasing power parity exchange rate rule to foster disinflation.

Consider what happens in an economy with considerable inflation inertia when an exchange rate-based stabilization is put in place. Starting with high inflation, assume the government reduces the rate of currency depreciation to zero. Although the new long-run equilibrium has zero inflation and the original real exchange rate, there are disruptive transitional effects.

The immediate effect of fixing the exchange rate is to cut the nominal interest rate and hence the real interest rate, so that demand increases. The inertia in prices plus the fixed nominal exchange rate generates an appreciation of the real exchange rate. As the appreciation continues, the original increase in demand erodes. In addition, the real interest rate increases, and, in the early phases of the program, the current account moves into deficit. The economy returns to full equilibrium, with reduced inflation, only after deflation has restored the initial level of competitiveness.

The model is oversimplified in a number of ways. First, there are no lags in the adjustment of demand and the current account to changes in 
the real exchange rate. Second, the adjustment to the real exchange rate assumes an immediate substitution effect, contrary to the Diaz-Alejandro effect. ${ }^{12}$ If during the first stages of the disinflation program the real appreciation is expansionary, this will further increase the overvaluation of the exchange rate, increasing the recession necessary to restore the original real exchange rate. Third, the monetary mechanism operates entirely through interest rates and there is no role for credit and confidence. Again, given the importance of the credit constraints that firms and consumers face, the remonetization of the economy that occurs when the nominal interest rate drops increases the amount of credit given by the banking sector. If liquidity constraints are important, one can observe that an increase in the supply of credit does not cause a decline in the real interest rate. Finally, wealth effects and asset processes play no role.

Even though these aspects of adjustment are absent, this highly stylized model captures the pattern of the adjustment process. It highlights, in particular, that, on the way to disinflation, high unemployment and large deficits make continuing the program increasingly difficult; if confidence breaks down, so does the financing of external balances. In this case, interest rates will soar, output will fall, and ultimately the program will be abandoned.

In Mexico, the exchange rate-based stabilization was complemented by incomes policy, and the disinflation from triple-digit levels was achieved largely through containment of wage increases. A simple model of this process follows. Price inflation comprises wage inflation and depreciation: ${ }^{13}$

$$
p=a w+(1-a) e,
$$

where $p$ equals price inflation, $w$ equals wage inflation, $e$ equals nominal exchange rate depreciation, and $a$ equals the proportion of wages in the total cost of production. Wage inflation is based on past inflation and the output relative to potential output:

$$
w=p_{-1}+c y,
$$

12. Diaz-Alejandro (1965) asserts that the income effect of a devaluation demands the substitution effect in the short run. If this is the case, an appreciation will be expansionary in the short run.

13. For a detailed exposition of the process, see Dornbusch (1993a). See Végh (1992) and Dornbusch and Fischer (1993) for references to the experience with exchange ratebased stabilization. 
where $y$ equals deviations of output from the natural level and $c$ is a parameter that measures the sensitivity of wages to cyclical conditions. Combining equations 5 and 6 yields an inflation rate that shows full persistence, so that inflation today equals inflation yesterday, except as there is unemployment or real appreciation:

$$
p=p_{-1}+a c y+(1-a)\left(e-p_{-1}\right) .
$$

In Mexico, the pacto contributed in two ways to the disinflation process. First, the explicit price agreements helped cope with the persistence issue: business, labor, and the government agreed to break the backward-looking indexation pattern. They agreed on limits consistent with an immediate disinflation. Second, the government helped in a major way by allowing real appreciation of the currency. Third, slow growth dampened any possibility of labor shortages.

We complete the model by looking at the determinants of real demand. Here, the level of the real exchange rate and real interest rates are the prime determinants. Combining these demand determinants with inflation in equation 7 and assuming uncovered interest rate parity yield an inflation process that emphasizes both the current difference between inflation and depreciation and the level of the real exchange rate.

But does this explain what happened in Mexico? We investigate to what extent the hypothesis based on price and wage setting is able to explain the extent of the appreciation that has been observed during the pacto. For this, we estimate the following equation for the 1984:21993:2 period using quarterly data. The equation comes from equation 7 , substituting the determinants of $y$ for $y$ and assuming uncovered interest rate parity:

$$
p-p_{-1}=c+d\left(e-p_{-1}\right)+f\left(e-p_{-1}\right) D+g(E-P)_{-1},
$$

where the dummy variable $D$ takes the value of one from 1984:2 to 1987:4, $E$ equals the nominal exchange rate (in logs), and $P$ equals the price level (in logs). The dummy accounts for the introduction of incomes policy, which interrupts the inertia of inflation. The estimated coefficients with their $t$-statistics in parentheses are $c$ equals -0.59 $(-1.56), d$ equals $0.66(7.4), f$ equals $-0.38(-3.03)$, and $g$ equals $0.00046(1.92) .{ }^{14}$ The estimates highlight the substantial degree of persistence that is present in the inflation process. They also capture the im-

14. The equation also controls for the impact of foreign interest rates and inflation on demand and hence inflation. 
Figure 12. Time Path of the Inflation Rate

Percent

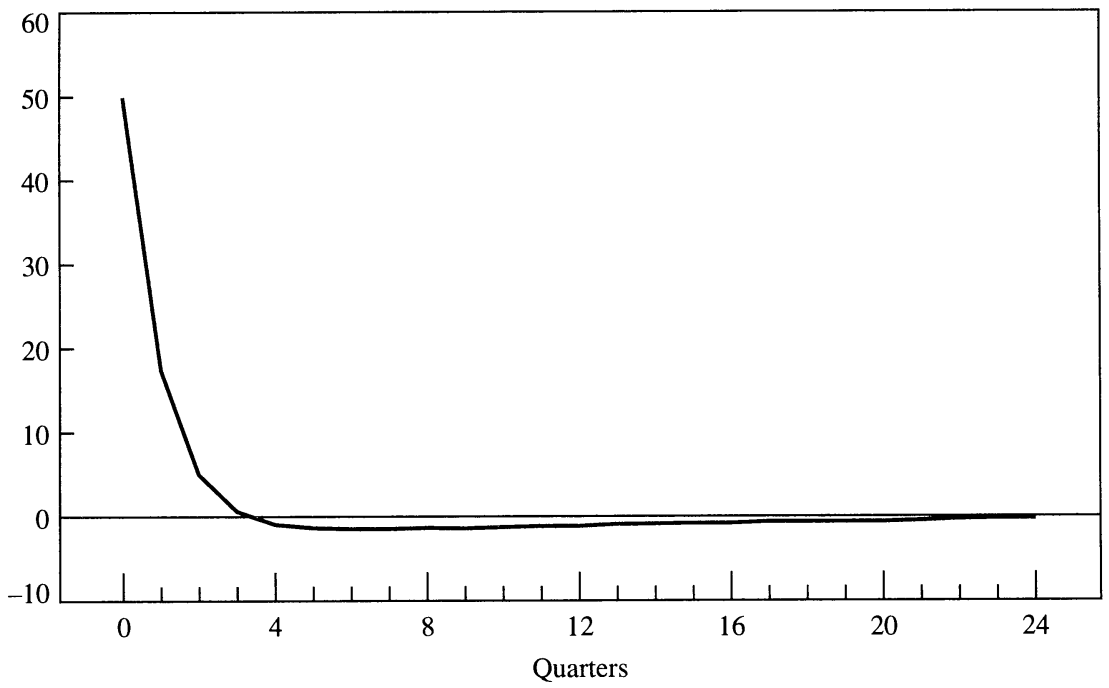

Source: Authors' simulations as described in the text.

portant reduction in inertia that was achieved during the exchange ratebased stabilization through wage and price agreements. The coefficient $f$ is negative and significant.

Using the estimated parameters, we now simulate the effect on the inflation rate and the real exchange rate of fixing the nominal exchange rate when quarterly inflation is running at about 50 percent (which was the quarterly rate in December 1987). Figures 12 and 13 show the time path of the inflation rate and the real exchange rate. Fixing the nominal exchange rate accomplishes a very substantial, rapid disinflation. Within a year, inflation evaporates. But the implications for the real exchange rate are just as striking. The large immediate real appreciation that is the price of fixing the nominal exchange rate is undone only gradually-over years (figure 13). Both aspects of our model are clearly present in the Mexican experience.

If the overvaluation hypothesis is correct, the return to a competitive real exchange rate will be a drawn-out process, in which slow growth and high unemployment are the chief vehicles of change. The alternative to a prolonged recession is a real depreciation-an issue to which we return below. 
Figure 13. Time Path of the Real Exchange Rate

Index, December $1980=100$

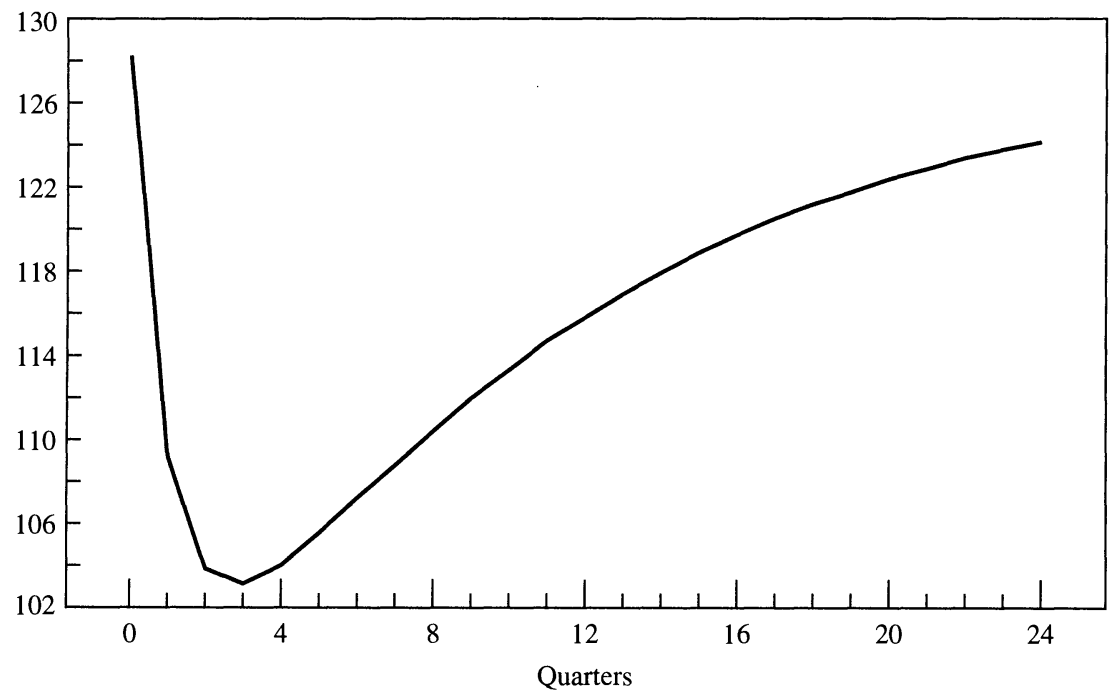

Source: Authors' simulations as described in the text

\section{More Arguments}

As we have noted, supporters of the equilibrium hypothesis hold that the external imbalance is not a problem. (Appendix B also discusses the equilibrium model in some detail.) They believe that it simply reflects the forces of reform and restructuring under way. A large deficit means that investment is running high and that capital goods are being imported to build the export base of tomorrow.

Their argument must be viewed with a dose of skepticism. The composition of imports shows that capital goods imports are not a leading item. In 1992, capital goods accounted for only 19 percent of total imports, intermediate goods for 69 percent, and consumer goods for close to 13 percent. The fastest growth item was consumption goods, which especially benefited from the trade liberalization. Table 9 shows Mexico's structure of imports.

Also, while it is true that investment has increased substantially in the past few years, as shown in table 10, much of that investment has been in residential and business structures not in plant and equipment. The overvaluation hypothesis explains investment as the result of the sharp drop in real interest rates that accompanies an exchange rate-based 
Table 9. Structure of Imports in Mexico, 1986 and 1992

Percent of total

\begin{tabular}{lrr}
\hline Type of goods & 1986 & 1992 \\
\hline Consumer & 5.0 & 12.5 \\
Intermediate & 77.3 & 68.9 \\
Capital & 17.7 & 18.6 \\
\hline
\end{tabular}

Source: Banco de México (1993, p. 311).

(temporarily credible) program. As a result of lower real interest rates and reduced inflation, credit markets reopen. The trade reform and overvaluation help reduce the cost of imported durables, and speculative elements surrounding a possible policy reversal reinforce the urge to buy. ${ }^{15}$

Another reason to disfavor the equilibrium model is that it has a hard time explaining the falls in output and employment that are gradually emerging. By contrast, the overvaluation model would predict that, beyond the initial expansion phase (the result of greater credit, higher real interest rates, and possibly rising real wages), overvaluation starts slowing demand and output. Carlos Diaz-Alejandro notes that real depreciation first depresses demand via income effects before stimulating demand via substitution effects, which come to dominate. ${ }^{16}$ In the case of Mexico, the argument applies in reverse: real appreciation first creates demand; then the drag of adverse substitution effects takes over.

Another way to test the usefulness of the two theoretical approaches is to look at the nominal interest rates on securities of different denominations. Why not look at dollar and peso securities issued by the Mexican government and recover the expectations of depreciation implicit in the yield differential? If the exchange rate is overvalued, depreciation is a possibility and the yield differential will reflect the extent of the misalignment.

We therefore look at financial data for evidence of whether the financial markets perceive the real appreciation or the increasing trade deficit as an equilibrium phenomenon (in which case they would not react to changes in the trade balance or the real exchange rate because that

15. Guillermo Calvo, in particular, has emphasized the speculative element. See, too, Dornbusch (1986).

16. Diaz-Alejandro (1965). 
Table 10. Growth and Investment in Mexico, 1989-93

Percent per year

\begin{tabular}{ccc}
\hline Year & $\begin{array}{c}\text { GDP } \\
\text { per capita }\end{array}$ & $\begin{array}{c}\text { Investment } \\
\text { (percent } \\
\text { of GDP) }\end{array}$ \\
\hline 1989 & 1.3 & 17.3 \\
1990 & 2.4 & 18.7 \\
1991 & 1.6 & 19.5 \\
1992 & 0.7 & 21.7 \\
1993 & -1.2 & 20.7 \\
\hline
\end{tabular}

Source: Authors' calculations based on unpublished data from INEGI and International Financial Statistics.

model does not predict such an adjustment). In table 11, we regress the interest rate differential (adjusted by the announced depreciation) for monthly data for the April 1988-June 1993 period on a trend (to account for improving program credibility as time passes), a dummy (to account for the announcement of the Brady plan in June 1989), the average maturity of public debt with one lag measured in days (to account for the fact that with a maturity the probability of a speculative attack diminishes), ${ }^{17}$ and the real exchange rate or the trade balance (in billions of dollars) with one lag. We use three interest rate differentials: the difference between the one-month cete (denominated in pesos) and the one-month certificate of deposit (CD) in the United States; the difference between the cete and the pagafe, which is a dollar-indexed instrument issued by the Mexican government; and the difference between the pagafe and the U.S. CD.

The real exchange rate is consistently insignificant in the regressions (not shown), but the expected devaluation measured by the cete-CD differential depends positively on the trade deficit. An increase of the (monthly) trade deficit of $\$ 1$ billion increases the interest rate differential by 2.5 percentage points. The reason why the cete-pagafe regression turns out poorly may be that, when the expected devaluation increases, the government issues more pagafes and, given that it faces a downward demand for pagafes, the price goes down so its yield goes up. This regression suggests that the government has been managing the composition of its domestic debt in order to respond to cost differentials.

17. Giavazzi and Pagano (1989). 
Table 11. Explaining Interest Rate Differentials ${ }^{\mathrm{a}}$

\begin{tabular}{|c|c|c|c|c|c|c|c|}
\hline $\begin{array}{l}\text { Dependent } \\
\text { variable }\end{array}$ & Constant & $\begin{array}{c}\text { Brady } \\
\text { plan } \\
\text { dummy }\end{array}$ & Trend $^{\mathrm{b}}$ & $\begin{array}{c}\text { Average } \\
\text { maturity } \\
\text { of public } \\
\text { debt } \\
(\text { lagged })^{\mathrm{c}}\end{array}$ & $\begin{array}{c}\text { Trade } \\
\text { balance } \\
\text { (lagged) }\end{array}$ & $\begin{array}{c}\text { Lagged } \\
\text { dependent } \\
\text { variable }\end{array}$ & $\begin{array}{c}\text { Twice- } \\
\text { lagged } \\
\text { dependent } \\
\text { variable }\end{array}$ \\
\hline $\begin{array}{c}\text { Cete-U.S. CD } \\
\text { differential }\end{array}$ & $\begin{array}{l}0.012 \\
(4.4)\end{array}$ & $\begin{array}{l}0.0027 \\
(1.9)\end{array}$ & $\begin{array}{l}-0.0113 \\
(-1.9)\end{array}$ & $\begin{array}{l}-0.0016 \\
(-2.3)\end{array}$ & $\begin{array}{l}-0.0021 \\
(-1.6)\end{array}$ & $\begin{array}{l}0.64 \\
(4.6)\end{array}$ & $\begin{array}{l}-0.14 \\
(-1.8)\end{array}$ \\
\hline $\begin{array}{l}\text { Cete-pagafe } \\
\text { differential }\end{array}$ & $\begin{array}{l}0.005 \\
(2.8)\end{array}$ & $\begin{array}{l}-0.0003 \\
(-3.0)\end{array}$ & $\begin{array}{l}-0.0035 \\
(-0.6)\end{array}$ & $\begin{array}{l}-0.0006 \\
(-1.1)\end{array}$ & $\begin{array}{l}-0.0009 \\
(-0.6)\end{array}$ & $\begin{array}{r}0.57 \\
(11.0)\end{array}$ & $\cdots$ \\
\hline $\begin{array}{c}\text { Pagafe-U.S. CD } \\
\text { differential }\end{array}$ & $\begin{array}{l}0.006 \\
(4.8)\end{array}$ & $\begin{array}{l}0.0029 \\
(3.5)\end{array}$ & $\begin{array}{l}-0.0093 \\
(-2.7)\end{array}$ & $\begin{array}{l}-0.0004 \\
(-1.0)\end{array}$ & $\begin{array}{l}-0.0009 \\
(-1.2)\end{array}$ & $\begin{array}{r}1.02 \\
(10.0)\end{array}$ & $\begin{array}{c}0.56 \\
(6.0)\end{array}$ \\
\hline
\end{tabular}

Sources: Authors' regressions based on data from Banco de México, Indicadores Económicos, various issues; and unpublished data from the Finance Ministry.

a. The dependent variables are the interest rate differential between the cete (a one-month peso-denominated government bond) and a one-month U.S. certificate of deposit (CD); a one-month cete and a pagafe (a dollar-indexed instrument issued by the Mexican government); and a pagafe and a one-month U.S. CD. Regressions use monthly data from April 1988 to June 1993. Numbers in parentheses are $t$-statistics.

b. Coefficient multiplied by 100 .

c. Measured in days; coefficient multiplied by 100 .

\section{Lessons of the Mexican Reforms}

We have explored two hypotheses of the macroeconomic developments in Mexico. One asserts that equilibrium prices of assets and dollar wages have risen as a result of various reform measures. This equilibrium view acknowledges no problems in the Mexican economy and hence offers no policy remedies. According to this view, NAFTA will reinforce confidence and help fortify the resolution of lenders. The new independent central bank will institutionalize financial stability and strengthen reform with beneficial effects on access to capital markets.

The disequilibrium view, by contrast, accepts the extraordinary reform effort and the prospective benefits of liberalization and NAFTA. But it recognizes, we believe rightly, that overvaluation is one of the gravest policy errors along the way. Overvaluation stops growth and, more often than not, ends in a speculative siege on the exchange rate and ultimately currency realignment. That sequence occurred in Europe a few years ago and has been repeated numerous times in Latin America. Chile, as mentioned earlier, overused the exchange rate in the 1970s and its economic program crashed; in the 1980s, Chile gave inflation control an important but not exclusive role, and as a result of the macroeconomic strategy growth in the latter period was highly satisfactory. In- 
deed, after a host of exchange rate-based stabilizations the lessons are clear. ${ }^{18}$

-First, a pegged exchange rate is immensely helpful at the outset of a stabilization effort. It helps rally expectations, and incomes policy can be organized around it. Moreover, a fixed rate can be counted on to immediately improve inflation performance.

- Second, almost without exception, a fixed rate will not imply zero inflation. Inflation will fall off, perhaps sharply, but it will not end altogether. Accordingly, there is a need to reassess very quickly when to abandon the fixed rate and settle for some inflation, though at a far more moderate rate than before the stabilization.

- Third, much of the disinflation must happen through the initial incomes policy package. Fixing only the exchange rate risks overvaluation.

-Fourth, a crawling peg that offsets the prevailing inflation with currency depreciation avoids an accumulation of real appreciation that would ultimately risk the success of stabilization. Yet, as useful as exchange rate pegging is at the outset, it is equally important to eliminate it as soon as possible.

-Fifth, incomes policy is helpful at the outset, but private sector competition must soon take over the work of keeping prices down.

How does the Mexican experience compare? Incomes policy was helpful initially but then got in the way. The pacto did help bring down 200 percent inflation very fast. It helped reduce indexation-explicit or implicit-and diminish inflation persistence, thus making the initial sharp disinflation possible. But the exchange rate soon became overused and the pacto process did not make further strides toward low inflation, except at the expense of competitiveness. In August 1991, an observer called for the pacto to move to a permanently fixed rate on the dollar:

Pacto-fatigue is a fact; it is hard to believe that the current policies can go on for another year or two. It is time to take the government out of wage-price setting and bring the market in. That is understood. The only issue is how to do it and

18. See Calvo and Végh (1992), Dornbusch and Simonsen (1987), Dornbusch (1986, 1993a, 1993b, and 1994), Dornbusch and Fischer (1993), Edwards (1993a, 1993b), Kiguel and Liviatan (1992), and further references cited in these publications. 
when. The answer here is one more pacto to safely land the economy, then declare victory and get out. When? The sooner the better. ${ }^{19}$

In February 1992 (before the European lessons of that fall) the story was still the same:

. . . no problem in anchoring the peso to the dollar, preferably without any margins so as to gain the maximum benefit of monetary integration and the maximum reduction in Mexican interest rates. But even as the peso is tied to the dollar, inflation should be pushed down to American levels rapidly. There is no interest in allowing a Spanish-style cumulative overvaluation which ultimately is hard to undo and which is bound to slow growth. ${ }^{20}$

Because of the complications caused by the persistent use of incomes policy, by early 1993 a rollback in the exchange rate was judged necessary. ${ }^{21}$ Of the options for doing so-recession; maxidevaluation; and increasing the pace of the crawl-the last was favored. Specifically,

The strategy of a faster crawl would accept an increase of inflation to 15-18 percent as the price for gaining competitiveness and the price for avoiding a recurrence of the exchange rate and social crises of the past election years. The pace of the crawl would be stepped up immediately to 22 percent per year, declining toward 17 percent over 18 months. . . The art of inflation fighting is to know when to stop. A wise US senator when asked for counsel on what to do about the unending Vietnam War advised: declare victory and get out. Mexico's authorities should reassess their priorities and shift to a model where growth comes first, but inflation is firmly contained below a 20 percent barrier. That is possible, as Chile's example of the past decade shows quite convincingly. ${ }^{22}$

To those who accepted that Mexico had a problem, waiting for the election year to end with still greater overvaluation was clearly a big mistake.

Learning from unsuccessful exchange rate-based stabilization in the 1970 s, Chilean policymakers of the 1980 s never made inflation the absolute and exclusive target; overvaluation never happened and growth was strong. ${ }^{23}$ That lesson should have been understood in Mexico two or three years ago. Regrettably, however, Mexican policymakers opted to replicate the mistakes of the 1970s Chilean strategy rather than the positive lessons of the 1980 s policy.

19. Dornbusch (1991, p. 6).

20. Dornbusch (1992).

21. See Dornbusch (1993a).

22. Dornbusch (1993a, p. 379).

23. See Dornbusch and Edwards (1994). 


\section{What Now for Mexico?}

What are the issues and options now facing Mexico? Since the start of 1994, several speculative attacks on the peso have occurred; at least $\$ 10$ billion in reserves were lost; a swap line with the United States was requested and granted; the stock market declined more than 30 percent; and short-term interest rates increased by more than 700 basis points. So, while there may not be any deep, fundamental problem, there is no arguing with the fact that the market has doubts about the economy.

\section{How Much Action Is Needed?}

At best, the current turbulence merely reflects ordinary election year uncertainties, and the basic economic fundamentals are sound. In this case, the very best strategy, for the ruling party and the country alike, is to maintain the exchange rate strategy (the band agreed in the last pacto), pursue high interest rates and borrow to cover the current account deficit, ride out the crisis and the elections, and prove the market wrong. Once the election is won and the continuity of policies is established (presuming the ruling party is reelected), the economic model and the strategy would be vindicated. Financial instability, devaluation, and inflation would be avoided, and credibility would increase. France in 1993-94-with its refusal to give up on the franc's fixed parity with the deutsche mark in the face of massive adverse speculation-provides an example of this sit-tight approach.

A closely related interpretation of Mexico's current position is that the current level of the exchange rate is probably wrong and that, for growth reasons, something needs to be done-but not in the midst of an election year. Politically, the loss of face inherent in a devaluation is troublesome, since so much rhetoric goes into defending the fixed-rate strategy. It is simply easier to allow high interest rates to prevail (as France did in 1993) until a more convenient (postelection) time comes to devalue.

Some others agree with the need for action..$^{24}$ Observers in this camp

24. In Mexico, this view has been entertained in some form or another during the past two or three years and has all the appearances of Akerlof's (1990) theory of procrastination. As Akerlof emphasizes, postponement of the inevitable by rationalizing the low costs of delay is irrational. In this instance, the accumulated costs of imbalances in the form of hysteresis effects of low growth and increased trade penetration make it more important to act early. 
believe that relying on the capital market's interpretation of the exchange rate can be risky, however, since the market may suddenly lose faith, and a country that is overextended in its borrowing may face imminent financial crisis. Given this risk, they favor a cautious policy that starts with competitiveness.

How valid are these views suggesting that only minor tinkering may be needed in Mexico? Much depends on the size of the overvaluation. For example, a minor overvaluation of 5 or 10 percent would be hard to identify and may disappear in response to positive reform or a more favorable external environment. But a large overvaluation will not go away on its own accord. Indeed, its costs will rise steeply: first, growth will slow; then, interest rates will be raised to defend the currency; then, the combination of low growth and high real interest rates will cause firms' balance sheets to deteriorate, and hence those of banks. Then active speculation starts.

This process has already begun in Mexico, suggesting an overvaluation that needs addressing. Growth is sluggish, and bad debts are accumulating. The realized real interest rates on bank loans, which are shown in figure 14 , have been averaging close to 15 percent over the past five years. The growth in nonperforming assets is therefore no surprise, a trend that is reinforced by the downturn in economywide growth. In the Mexican banking system, nonperforming loans have already increased from 2.0 percent of total loans in 1989 to 7.1 percent in 1993. The election year growth in the macroeconomy may alleviate the problem for a while, but ongoing overvaluation will not go away, and 1994 is at best a reprieve.

Mexico's vulnerability to the problems inherent in an overvaluation is accentuated by the uncertainty surrounding Mexico's political future. Mexico's rapid embrace of greater political openness has shattered the ruling party's historical coherence, so that the old corporatism becomes unmanageable. Moreover, too much adjustment has been left for the postelection government. The rest of the world understands what the changes in Mexican politics mean-as the recent volatility in Mexican financial markets makes clear.

Unless the exchange rate is devalued, either recession will be needed to eliminate the external problem and reduce inflation or expansion will be needed to alleviate the lack of growth. Neither option is realistic. It is politically difficult to squeeze inflation through recession, and fiscal stimulus, although more tempting, is not a feasible long-run solution in 
Figure 14. Average Real Lending Rate, 1990-93

Percent

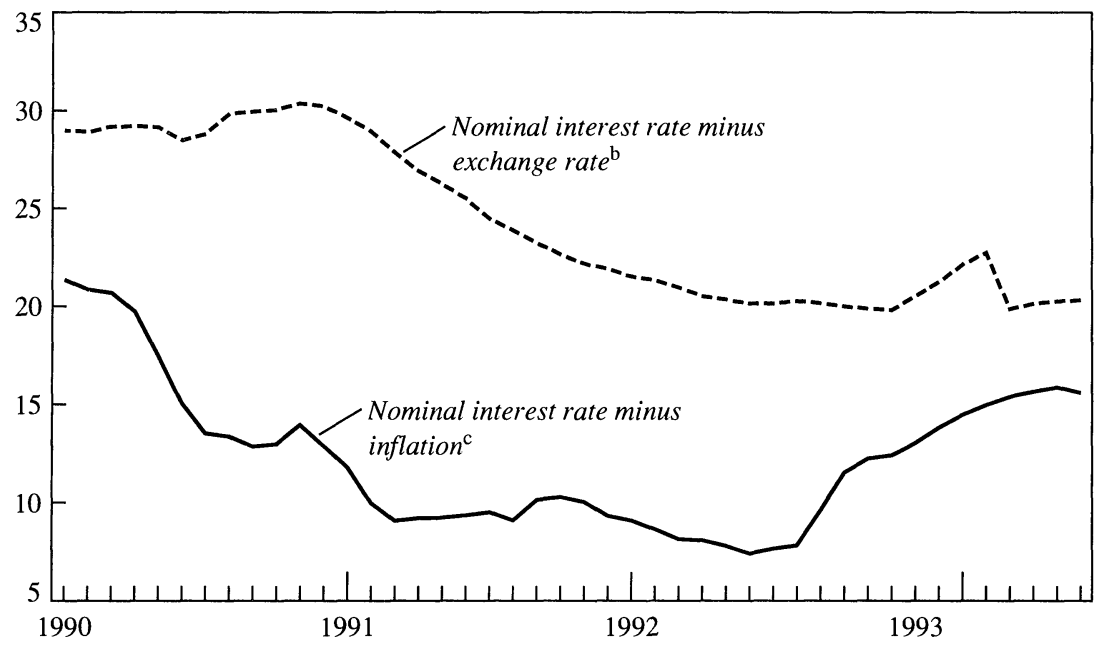

Source: Authors' calculations based on Banco de México, Indicadores Económicos, various issues.

a. The nominal interest rate is based on the CPP, an average interest rate in Mexico similar to the prime rate, plus 5 percent. The series are plotted as 12-month moving averages.

b. Real interest rate is calculated using the nominal rate described in note a minus the depreciation of the exchange rate (pesos per dollar).

c. Real interest rate is calculated using the nominal rate described in note a minus consumer price inflation.

Mexico. We believe instead that a significant departure from the present exchange rate is needed.

\section{Exchange Rate Strategies}

As we have argued throughout this paper, only some of the 40 percent real appreciation (measured in relative wholesale prices) since $1988 \mathrm{can}$ be credited to the sharply improved economic conditions in Mexico. The rest is suspect. In fact, the recent 6 percent realignment inside the exchange rate band passed with little chaos or fear, suggesting there is room for greater devaluation, but it must occur soon. There were several days following the assassination of candidate Colosio during which the nation rallied behind the official party and that could have provided the cover for a realignment. But it is doubtful how much of this momentum remains.

What then are plausible exchange rate strategies given the present predicament? To answer that question requires asking two other supporting questions. First, is there further pacto support for a change in 
Table 12. Policy Issues and Options

\begin{tabular}{llc}
\hline & $\begin{array}{c}\text { Acute } \\
\text { problem }\end{array}$ & $\begin{array}{c}\text { No acute } \\
\text { problem }\end{array}$ \\
\hline Pacto support & Devalue & Crawl \\
No pacto support & Float & Get support \\
\hline
\end{tabular}

the exchange rate policy?25 Second, how acute is the current problem? Table 12 presents a matrix of options under four different scenarios.

We first look at the two cases in which pacto support exists. We believe such support can be mobilized, and with it Mexico could manage "one last devaluation." If overvaluation is an acute problem and pacto support is possible, a 20 percent devaluation is the preferred strategy in our view. Using the trade equations shown in appendix C, a 20 percent devaluation would reduce the trade deficit to approximately zero. This would stimulate growth and reduce the precarious financial dependence.

If overvaluation is not acute but pacto support exists, a crawling depreciation is a good solution. This (inflationary) strategy takes time, but it does reduce some of the pressure on the exchange rate and has lower political costs. It is decidedly not an emergency procedure.

Even if we are wrong about the potential pacto support, however, a realignment will be essential. If the currency is not devalued, growth will not keep pace with the growth of the labor force; the divisions in Mexican society will widen; and national stability will be threatened. But what is the best exchange rate strategy if union support is lacking? In this case, a devaluation could quickly translate into political agitation for wage increases. Inflation might shoot up, and expectations of a second devaluation would rise with it. Interest rates would stay high in real terms; external capital would be reluctant to come to or stay in Mexico; and growth would suffer. It is easy to recall experiences of this kind, but that does not make such outcomes inevitable. For example, recent major devaluations in Finland, Sweden, Italy, Spain, and the United Kingdom did not lead to inflation-in fact, it has come down, as have interest rates. Devaluation was a boon to these countries. If the overvaluation is not critical, the best strategy may be to "get support" from the unions before proceeding.

25. The pacto negotiations normally seek exchange rate and wage targets. However, neither of these measures prevents all real depreciation. 
Without pacto support and with a pressing overvaluation problem, the answer is to use the current crisis to discard the pacto process and move to a floating rate. The peso would be allowed (by lower nominal interest rates) to fall about 20 percent. Monetary and fiscal policies would face the hard challenge of allowing the real depreciation and preventing a resurgence of major inflation. There is no assurance that this strategy must work; but it is the only option if realignment is to be sought outside a pacto accord. Doing nothing in the face of an increasingly tenuous currency situation means that these problems will be faced at an even less convenient time, with more surprise and less control.

To conclude, President Carlos Salinas de Gortari is rightly acknowledged for the sweeping reforms in Mexico, but he left two loose ends. The first was postponing real democracy in favor of another six years of technocratic rule. The other was overvaluing the currency. For Salinas, inflation was the primary issue, just as it had been in Chile in the late 1970s. In his own words,

We must bring inflation down to a one-digit level this year. Some say, why don't you relax your inflation goals a bit so we can have better growth rates? And I respond: There is no trade-off between inflation and growth..$^{26}$

The evidence of the past few years contradicts his statement. Disinflation with overvaluation is a temporary device that ultimately causes great damage. In Mexico, that sad ending lies ahead unless the currency is devalued.

\section{APPENDIX A}

\section{The Pacto Agreements, 1987-9327}

\section{December 1987-February 1988}

Tax measures: Elimination of subsidies, except for agriculture. Elimination of the accelerated depreciation incentive and an additional import tax. Adjustment in public sector prices. Reduction in programmable spending by 1.5 percent of gross domestic product. Exchange rate policy to support deflation without sacrificing competitiveness.

26. Geri Smith, "Salinas Faces His Toughest Year Yet," Business Week, February 1, 1993, p. 41.

27. Aspe (1993), updated with information from Banco de México and Presidencia de la República (1994). 
Trade policy: Reduction of the maximum import tariff from 40 percent to 20 percent and the elimination of import permits. Minimum-wage increase of 35 percent, and monthly review according to anticipated inflation. Price agreements for basic products.

\section{March-April 1988}

Constant public sector goods prices and tariffs. Exchange rate fixed at its level on February 29, 1988 (2,297 pesos to the dollar). A 3 percent increase in minimum and contractual wages.

\section{April-May 1988}

Fixed public sector prices and fees, controlled prices, and minimum wages. Fixed exchange rate until May 31, 1988.

\section{June-August 1988}

Fixed public sector prices and fees; wages and controlled prices. Fixed exchange rate until August 31, 1988.

\section{September-December 1988}

Constant prices, fees, and minimum wages. Exchange rate fixed. Valueadded tax reduction from 6 percent to 0 percent in unprocessed foods and medicines. Income tax reduction of 30 percent for people who earn up to four times the minimum wage. Agreement by business to lower prices by 3 percent.

\section{January-July 1989}

Public sector prices that are most important in the consumption basket to remain constant. Exchange rate against the dollar to crawl at one peso a day. (Equivalent to an annual rate of depreciation of 16 percent.) Reduction of import tariff dispersion. Rise in support prices of agricultural products to maintain their real level.

\section{August 1989-March 1990}

Public sector prices constant. The rate of crawl at one peso a day. Firms to maintain prices and controlled prices, reviewed on a case-by-case basis. Government commitment to speed up the deregulation process.

\section{January 1990-December 1990}

Adjustment of minimum wages according to expected inflation. Crawling peg set at 80 centavos a day. (Equivalent to an annual rate of depreciation of 11 percent.) Adjustment of public sector prices to comply with revenue goals of the budget. Revision of controlled prices on a case-bycase basis. 


\section{December 1990-December 1991}

Adjustment of minimum wages to maintain purchasing power. Crawl of the exchange rate reduced to 40 centavos a day. (Equivalent to an annual rate of depreciation of 5 percent.) Public sector prices increased in November 1990 and fixed throughout 1991. Revision of controlled prices on a case-by-case basis.

\section{December 1991-December 1992}

Adjustment of minimum wages to restore purchasing power. A target zone for the exchange rate introduced. Ceiling of the band depreciated 20 centavos a day. (Equivalent to an annual rate of depreciation of 2.3 percent.) Floor of the band kept constant. Adjustment of public sector prices. Value-added tax reduced from 15 percent to 10 percent. Revision of controlled prices on a case-by-case basis.

\section{December 1992-December 1993}

Wage increases settled within the target rate of inflation. One-digit increases in electricity for domestic use and gasoline. Crawl for the ceiling of the currency band increased to 40 centavos a day. (An annual rate of depreciation of 4.6 percent.) Floor kept constant. Further deregulation of economic activity announced.

\section{December 1993-December 1994}

Ceiling of the currency band depreciated 40 centavos a day. Floor kept constant. Minimum wages adjusted by the target inflation rate (5 percent) plus the average increase in labor productivity. Reduction in taxes paid by low-income workers.

Reduction in public prices of industrial inputs. The maximum income tax rate for firms decreased from 35 percent to 34 percent. Other fiscal incentives for investment introduced.

\section{APPENDIX B}

\section{The Model}

HeRE WE SKETCH our basic model. ${ }^{28}$ In the home goods market, spending is a given share of labor income, $P_{N} D=a W L(1-t)$, where $P_{N}$ is the price of nontradables, $D$ is the quantity demanded of nontradables, $L$ is

28. The model extends work by Kouri (1979) and Dornbusch (1989). 
the labor supply, and $t$ is the income tax rate. The price of home goods is given by the unit labor cost, $b W$. We assume $b$ is equal to unity for simplicity. The government spends $G$ on nontraded goods. Hence labor demand originating in the home goods market is $L_{N}=a(1-t) L+G$.

Investment involves the installation of capital subject to an increasing marginal cost. Investment involves only importables. Hence the equilibrium rate of investment is a function of the price of capital in terms of imported machinery. Given world prices, the exchange rate proxies for the domestic price of imported machinery, $I=I\left(P_{K} / E\right)$, where $P_{K}$ is the price of capital goods and $E$ is the nominal exchange rate. This real price of capital is denoted by Tobin's $q$. Capital formation is given by investment less the rate of depreciation, $\dot{K}=\mathrm{I}(q)-d K$. Note that if the installation of capital requires labor, the wage in dollars would become a determinant of the rate of investment. In that case, a higher wage in dollars would reduce the rate of investment.

In the traded goods sector, firms produce with a neoclassical production function. Labor demand is a function of the product wage or the wage in dollars, $w=W / E$, and of the capital stock, $L_{T}=f(w) K$.

Labor market equilibrium prevails at a wage in dollars that balances the full employment labor supply and the demand for labor from the two sectors:

$$
L=f(w) K+a(1-t) L+G,
$$

which yields the equilibrium wage

$$
w=w(\stackrel{+}{K}, \stackrel{+}{G}, \bar{t}) .
$$

The model is closed with an arbitrage equation for the capital market. With perfect substitution between domestic installed capital and assets abroad, returns in dollars adjusted for political risks and including capital gains must be equalized:

$$
R(w) / q+\dot{q} / q=i^{*} .
$$




\section{APPENDIX C}

\section{Trade Equations}

To ASSESS THE EFFECT of the real exchange rate on the trade balance, we estimated a demand for imports (disaggregated by type of goods) and the supply and demand for nonoil exports. We also compare our results with a previous study for Mexico. First, we present our estimations and then we provide a summary of other results. All variables are in logs, and all dollar values are deflated by the U.S. PPI.

\section{Import Functions}

We estimated a different demand function for each class of goodsconsumption, intermediate, and capital-and then for the aggregate. The independent variables used in each case were real gross domestic product and two dummy variables, POL1 and POL2. POL1 takes the value of one for 1984:1-1985:4 and zero afterward in order to capture the substitution of quotas for tariffs that took place at the end of 1985 (quota coverage dropped from 100 percent to 28 percent between June and December of 1985). The second dummy, POL2, takes the value of one from 1984:1 to 1987:4 and accounts for the reduction in tariffs that took place at the end of 1987. (The production-weighted tariff went from 22.7 percent to 11.8 percent between June and December of 1987.) To account for the fact that there might be a partial adjustment of equilibrium, we also included the lagged endogenous variable as a regressor. Other variables included seasonal dummies and the relative price of imports, $R P_{i}$-for capital and intermediate goods, the U.S. PPI (multiplied by the exchange rate) divided by the Mexican PPI; for consumer goods, the U.S. PPI (multiplied by the exchange rate) divided by the Mexican CPI. The estimated equation is

$$
\text { (C-1) } \begin{aligned}
I M P(i)= & c+b_{0} G D P+b_{1} R P_{i}+b_{2} P O L 1+b_{3} P O L 2 \\
& +b_{4} \text { Dum } 1+b_{5} \text { Dum } 2+b_{6} \text { Dum } 3+b_{7} I M P(i)_{t-1} .
\end{aligned}
$$

The results (for the 1984:1-1993:2 period) with $t$-statistics in parenthesis are shown in table $\mathrm{C} 1$. We omit the seasonal dummies. 
Table C1. Explaining Import Demand, 1984-93

\begin{tabular}{|c|c|c|c|c|c|c|c|}
\hline \multirow[b]{2}{*}{$\begin{array}{c}\text { Dependent } \\
\text { variable }\end{array}$} & \multirow[b]{2}{*}{ Constant } & \multicolumn{5}{|c|}{ Independent variable } & \multirow[b]{2}{*}{$\bar{R}^{2}$} \\
\hline & & $G D P$ & $\begin{array}{l}\text { Relative } \\
\text { price of } \\
\text { imports }^{\mathrm{b}}\end{array}$ & $\begin{array}{c}\text { Tariff } \\
\text { substitution } \\
\text { dummy }\end{array}$ & $\begin{array}{l}\text { Tariff } \\
\text { reduction } \\
\text { dummy }\end{array}$ & $\begin{array}{c}\text { Lagged } \\
\text { dependent } \\
\text { variable }\end{array}$ & \\
\hline Capital goods & $\begin{array}{c}-3.71 \\
(-1.2)\end{array}$ & $\begin{array}{l}1.60 \\
(2.1)\end{array}$ & $\begin{array}{c}-0.08 \\
(-0.4)\end{array}$ & $\begin{array}{r}-0.05 \\
(-0.8)\end{array}$ & $\begin{array}{c}0.13 \\
(2.0)\end{array}$ & $\begin{array}{c}0.61 \\
(4.5)\end{array}$ & 0.96 \\
\hline Intermediate goods & $\begin{array}{l}1.11 \\
(0.9)\end{array}$ & $\begin{array}{l}1.40 \\
(3.4)\end{array}$ & $\begin{array}{c}-0.39 \\
(-3.4)\end{array}$ & $\begin{array}{c}0.02 \\
(1.0)\end{array}$ & $\begin{array}{c}0.15 \\
(3.7)\end{array}$ & $\begin{array}{c}0.35 \\
(3.1)\end{array}$ & 0.98 \\
\hline Consumption goods & $\begin{array}{c}0.21 \\
(0.3)\end{array}$ & $\begin{array}{r}0.50 \\
(0.7)\end{array}$ & $\begin{array}{c}-0.37 \\
(-1.5)\end{array}$ & $\begin{array}{c}-0.03 \\
(-0.4)\end{array}$ & $\begin{array}{c}0.32 \\
(3.5)\end{array}$ & $\begin{array}{c}0.70 \\
(8.7)\end{array}$ & 0.98 \\
\hline Total demand & $\begin{array}{c}0.08 \\
(0.1)\end{array}$ & $\begin{array}{r}1.25 \\
(2.8)\end{array}$ & $\begin{array}{l}-0.30 \\
(-2.7)\end{array}$ & $\begin{array}{l}0.006 \\
(0.2)\end{array}$ & $\begin{array}{l}0.15 \\
(3.8)\end{array}$ & $\begin{array}{c}0.52 \\
(5.3)\end{array}$ & 0.98 \\
\hline
\end{tabular}

Sources: Authors' regressions based on data from Banco de México, Indicadores Económicos, various issues; and International Financial Statistics.

a. The dependent variable is a demand function for the class of goods specified in the first column. Regressions use quarterly data from 1984:1-1993:2. The numbers in parentheses are $t$-statistics. All variables are expressed in logs.

b. For capital and intermediate goods, the relative price is the U.S. producer price index divided by the Mexican producer price index; for consumer goods, the relative price is the U.S. PPI divided by the Mexican consumer price index, in a common currency.

\section{Export Equations}

Since Mexico does not face a perfectly elastic demand for its exports, we estimated the supply and demand for Mexico's exports by instrumental variables in order to assess how the total return from exports will change when the exchange rate changes. The export demand and supply equations were estimated for the period 1984:1-1992:4. We postulate that

$$
\begin{aligned}
& X^{s}=c+b_{0} G D P+b_{1} \text { trend }+b_{2} R P_{s}+b_{3} X_{t-1}^{s}, \\
& X^{d}=d+a_{0} I M P_{U S}+a_{1} R P_{d}+a_{2} X_{t-1}^{d},
\end{aligned}
$$

where $R P_{s}$ equals the price of nonoil exports divided by the Mexican CPI, $R P_{d}$ equals the price of nonoil exports divided by the U.S. PPI, and $I M P_{U S}$ equals total U.S. imports.

We use $I M P_{U S}$ and $P P I_{U S}$ as instruments in the supply equation, and GDP and the domestic price level in the demand for exports:

$$
\begin{gathered}
\text { (C-3) } X_{s}=-3.6+0.66 G D P+0.025 \text { trend }+1.5 R P_{i}+0.31 X_{t-1}^{s} \\
\begin{array}{c}
(-0.9)(1.2) \\
(2.7)
\end{array} \\
\overline{\mathrm{R}}^{2}=0.89
\end{gathered}
$$


Table C2. Comparing Long-Run Price Elasticities for Mexican Imports and Exports

\begin{tabular}{|c|c|c|c|}
\hline $\begin{array}{c}\text { Measured long-run } \\
\text { elasticity }\end{array}$ & Estimated function & $\begin{array}{c}\text { Authors' } \\
\text { estimates, } \\
1984-93^{\mathrm{a}}\end{array}$ & $\begin{array}{c}\text { Van } \\
\text { Wijnbergen's } \\
\text { estimates, } \\
1965-87^{\mathrm{a}}\end{array}$ \\
\hline $\begin{array}{l}\text { Price elasticity } \\
\text { of imports }\end{array}$ & $\begin{array}{l}\text { Total } \\
\text { Capital goods } \\
\text { Intermediate goods } \\
\text { Consumption goods }\end{array}$ & $\begin{array}{l}-0.62 \\
-0.20 \\
-0.60 \\
-1.23\end{array}$ & $\begin{array}{r}\cdots \\
-1.68 \\
-0.64 \\
-3.35\end{array}$ \\
\hline $\begin{array}{l}\text { Activity elasticity } \\
\text { of imports }{ }^{b}\end{array}$ & $\begin{array}{l}\text { Total } \\
\text { Capital goods } \\
\text { Intermediate goods } \\
\text { Consumption goods }\end{array}$ & $\begin{array}{l}2.50 \\
4.10 \\
2.15 \\
1.60\end{array}$ & $\begin{array}{l}\cdots \\
0.71 \\
2.84 \\
1.31\end{array}$ \\
\hline $\begin{array}{l}\text { Elasticity of nonoil } \\
\text { exports }\end{array}$ & $\begin{array}{l}\text { Demand }^{c} \\
\text { Supplyd }^{d}\end{array}$ & $\begin{array}{r}-1.57 \\
2.17\end{array}$ & $\begin{array}{r}-1.07 \\
\ldots\end{array}$ \\
\hline
\end{tabular}

Sources: Authors' calculations based on data described in table C1; and van Wijnbergen (1990).

a. Authors' estimates are for quarterly data; van Wijnbergen's are for yearly data.

b. GDP is used as a measure of economic activity for the authors' calculations. Van Wijnbergen uses investment as a measure of activity for capital goods, total consumption goods for consumption goods, and output for intermediate goods.

c. U.S. demand function for Mexican imports.

d. Supply of Mexican exports.

$$
\begin{gathered}
X^{d}=-20.0+1.3 I M P_{U S}+0.66 R P_{d}+0.58 X_{t-1}^{d} \\
(-5.0)(5.2) \quad(4.4) \\
\overline{\mathrm{R}}^{2}=0.89
\end{gathered}
$$

With these results, we calculate the long-run elasticity of imports and the demand and supply of nonoil exports. Table $\mathrm{C} 2$ summarizes our results and other estimates for Mexico. 


\section{APPENDIX D}

\section{Indicators of the Mexican Economy}

The FOllowing TABLES provide detailed information on Mexican economic performance between 1980 and 1994. Table D1 presents measures of the terms of trade, exchange rate, and wages. Table D2 gives public finance indicators. Tables D3 and D4 provide general data on gross domestic product, employment, and the external sector. Table D5 shows financial and exchange rate data and inflation figures.

Table D1. Real Exchange Rate, Terms of Trade, and Real Wages in Mexico, 1980-93

Index, $1980=100$

\begin{tabular}{|c|c|c|c|c|c|c|c|c|}
\hline Year & $\begin{array}{c}\text { Real } \\
\text { exchange } \\
\text { rate }^{\mathrm{a}, \mathrm{b}}\end{array}$ & $\begin{array}{c}\text { Real } \\
\text { exchange } \\
\text { rate }^{\mathrm{a}, \mathrm{c}}\end{array}$ & $\begin{array}{c}\text { Real } \\
\text { exchange } \\
\text { rate }^{\mathrm{a}, \mathrm{d}}\end{array}$ & $\begin{array}{c}\text { Terms of } \\
\text { trade }\end{array}$ & $\begin{array}{l}\text { Terms of } \\
\quad \text { trade } \\
\text { adjusted }^{\mathrm{e}}\end{array}$ & $\begin{array}{c}\text { Minimum } \\
\text { wage }\end{array}$ & $\begin{array}{c}\text { Real } \\
\text { wages, } \\
\text { manufac- } \\
\text { tures }\end{array}$ & $\begin{array}{c}\text { Real } \\
\text { wages, } \\
\text { maquila- } \\
\text { dora } \\
\text { opera- } \\
\text { tions }\end{array}$ \\
\hline 1980 & 100.00 & 100.00 & 100.00 & 100.00 & 100.00 & 100.00 & 100.00 & 100.00 \\
\hline 1981 & 118.72 & 124.43 & 106.71 & 97.47 & 112.41 & 101.40 & 104.68 & 100.91 \\
\hline 1982 & 86.80 & 91.87 & 75.84 & 84.98 & 76.33 & 110.91 & 103.21 & 110.65 \\
\hline 1983 & 79.73 & 52.23 & 67.98 & 77.63 & 61.52 & 79.30 & 79.48 & 87.29 \\
\hline 1984 & 97.20 & 54.47 & 81.08 & 76.13 & 62.77 & 75.07 & 74.72 & 85.88 \\
\hline 1985 & 100.94 & 54.42 & 83.56 & 72.02 & 64.18 & 73.34 & 76.66 & 85.55 \\
\hline 1986 & 69.15 & 35.66 & 67.68 & 51.86 & 46.90 & 79.76 & 65.74 & 83.52 \\
\hline 1987 & 63.64 & 33.33 & 67.17 & 57.31 & 59.40 & 89.95 & 66.00 & 85.03 \\
\hline 1988 & 77.44 & 41.32 & 82.39 & 51.78 & 53.63 & 51.92 & 64.65 & 81.21 \\
\hline 1989 & 84.09 & 47.79 & 84.24 & 54.47 & 57.18 & 54.52 & 70.41 & 86.98 \\
\hline 1990 & 84.22 & 50.10 & 87.68 & 55.57 & 60.99 & 50.81 & 72.92 & 87.55 \\
\hline 1991 & 92.61 & 54.52 & 98.34 & 51.94 & 57.71 & 46.40 & 77.23 & 86.24 \\
\hline 1992 & 98.90 & 59.09 & 108.14 & 51.62 & 56.74 & 40.17 & 83.34 & 87.49 \\
\hline 1993 & 102.80 & 59.79 & 114.82 & 49.40 & 55.10 & 39.56 & 81.89 & 83.87 \\
\hline
\end{tabular}

Sources: Authors' calculations based on real exchange rate and terms of trade data from Banco de México (1993) and from International Financial Statistics; wage, exchange rate, and terms of trade data from Salinas de Gortari (1993); and the relative price measure of the real exchange rate from Morgan Guaranty Trust Company (various issues).

a. An increase in the real exchange rate index indicates appreciation.

b. The real effective exchange rate estimated on the basis of consumer prices for 133 countries.

c. The real effective exchange rate estimated on the basis of unit labor costs for Mexico's six largest trading partners: United States, Germany, Japan, Canada, United Kingdom, and France. These countries account for 85 percent of Mexico's trade in manufactures.

d. The Mexico-U.S. wholesale relative price levels.

e. Takes into account the effect of international interest rates on the cost of debt service. 
Table D2. Public Finance Indicators for Mexico, 1980-93

Percent of GDP

\begin{tabular}{|c|c|c|c|c|c|c|c|}
\hline Year & $\begin{array}{l}\text { Public sector } \\
\text { borrowing }(-) \\
\text { requirements }\end{array}$ & $\begin{array}{l}\text { Primary } \\
\text { balance }^{\mathrm{a}}\end{array}$ & $\begin{array}{c}\text { Operational } \\
\text { balance }^{\mathrm{b}}\end{array}$ & $\begin{array}{l}\text { Public } \\
\text { sector } \\
\text { total } \\
\text { revenues }\end{array}$ & $\begin{array}{c}\text { Oil } \\
\text { revenues }^{\mathrm{c}}\end{array}$ & $\begin{array}{c}\text { Domestic } \\
\text { debt }^{\mathrm{d}}\end{array}$ & $\begin{array}{c}\text { Foreign } \\
\text { debt }\end{array}$ \\
\hline 1980 & -7.5 & -3.0 & -3.6 & 25.5 & 7.8 & 9.9 & 15.5 \\
\hline 1981 & -14.1 & -8.0 & -10.0 & 25.2 & 7.7 & 12.2 & 16.5 \\
\hline 1982 & -16.9 & -7.3 & -5.5 & 27.8 & 11.1 & 15.5 & 35.8 \\
\hline 1983 & -8.6 & 4.2 & 0.4 & 31.7 & 16.1 & 16.5 & 43.7 \\
\hline 1984 & -8.5 & 4.8 & -0.3 & 31.3 & 15.1 & 18.8 & 38.3 \\
\hline 1985 & -9.6 & 3.4 & -0.8 & 30.4 & 13.3 & 16.8 & 40.0 \\
\hline 1986 & -16.0 & 1.6 & -2.4 & 29.4 & 11.3 & 18.3 & 60.2 \\
\hline 1987 & -16.0 & 4.7 & 1.8 & 29.5 & 12.0 & 19.5 & 54.3 \\
\hline 1988 & -13.0 & 8.0 & -3.6 & 29.1 & 10.1 & 19.0 & 43.9 \\
\hline 1989 & -5.6 & 7.9 & -1.7 & 27.7 & 9.0 & 17.6 & 39.0 \\
\hline 1990 & -3.9 & 7.8 & 2.2 & 27.5 & 8.8 & 16.9 & 30.1 \\
\hline \multirow[t]{2}{*}{1991} & 2.0 & 9.1 & 6.4 & 25.8 & 2.9 & 15.6 & 20.6 \\
\hline & $(-1.5)^{\mathrm{e}}$ & $(5.3)^{e}$ & $(3.3)^{\mathrm{e}}$ & $\ldots$ & $\ldots$ & $\ldots$ & $\ldots$ \\
\hline \multirow[t]{2}{*}{1992} & 3.5 & 8.8 & 5.9 & 26.0 & 2.5 & 10.1 & 16.4 \\
\hline & $(0.5)^{\mathrm{e}}$ & $(5.6)^{e}$ & $(3.6)^{e}$ & . . & $\ldots$ & $\ldots$ & $\ldots$ \\
\hline 1993 & 1.0 & 4.0 & 1.9 & 25.4 & 2.5 & $7.6^{f}$ & $14.3^{\mathrm{f}}$ \\
\hline
\end{tabular}

Source: Authors' calculations based on Presidencia de la República (1994) and Banco de México (1993).

a. Public sector borrowing requirements plus interest payments.

b. Adjusts public sector borrowing requirements by the inflationary component of interest payments on domestic debt.

c. Methodology for calculations was changed in 1991, so figures prior to 1991 are not comparable with those after 1991.

d. Debt figures are the public sector consolidated with Banco de México.

e. Numbers exclude revenues from privatization.

f. Estimates.

Table D3. Gross Domestic Product and Employment in Mexico, 1980-93

Index, $1980=100$

\begin{tabular}{lcccccc}
\hline Year & $\begin{array}{c}\text { Real } \\
\text { GDP }\end{array}$ & $\begin{array}{c}\text { Real GDP } \\
\text { per capita }\end{array}$ & $\begin{array}{c}\text { Employment } \\
\text { manufac- } \\
\text { turing }\end{array}$ & $\begin{array}{c}\text { Employment, } \\
\text { maquiladora } \\
\text { operations }\end{array}$ & $\begin{array}{c}\text { Social } \\
\text { security } \\
\text { enrollment }\end{array}$ & Population \\
\hline 1980 & 100.00 & 100.00 & 100.00 & 100.00 & 100.00 & 100.00 \\
1981 & 107.95 & 105.39 & 105.47 & 109.56 & 112.76 & 102.43 \\
1982 & 107.35 & 102.41 & 103.05 & 106.28 & 112.16 & 104.82 \\
1983 & 102.85 & 95.95 & 93.37 & 126.20 & 114.89 & 107.19 \\
1984 & 106.56 & 97.28 & 92.45 & 167.04 & 124.43 & 109.55 \\
1985 & 109.32 & 97.71 & 94.40 & 177.31 & 129.69 & 111.89 \\
1986 & 105.22 & 92.11 & 92.50 & 208.98 & 133.26 & 114.23 \\
1987 & 107.17 & 91.94 & 92.67 & 255.34 & 142.37 & 116.57 \\
1988 & 108.51 & 91.24 & 92.43 & 309.08 & 150.31 & 118.92 \\
1989 & 112.14 & 92.46 & 94.59 & 350.10 & 160.49 & 121.29 \\
1990 & 117.12 & 94.71 & 94.72 & 374.42 & 172.28 & 123.67 \\
1991 & 121.37 & 96.25 & 93.12 & 390.94 & 180.74 & 126.10 \\
1992 & 124.59 & 96.93 & 89.48 & 422.48 & 179.19 & 128.54 \\
1993 & 125.10 & 95.50 & 85.03 & 447.87 & 179.37 & 131.00 \\
\hline
\end{tabular}

Sources: Authors' calculations based on Salinas de Gortari (1993) and International Financial Statistics. 
Table D4. External Sectora

Billions of dollars

\begin{tabular}{|c|c|c|c|c|c|c|c|c|c|}
\hline Year & $\begin{array}{c}\text { Total } \\
\text { exports }\end{array}$ & $\begin{array}{l}\text { Nonoil } \\
\text { exports }\end{array}$ & $\begin{array}{c}\text { Total } \\
\text { imports }\end{array}$ & $\begin{array}{c}\text { Consump- } \\
\text { tion } \\
\text { imports }\end{array}$ & $\begin{array}{l}\text { Interme- } \\
\text { diate } \\
\text { goods } \\
\text { imports }^{\mathrm{b}}\end{array}$ & $\begin{array}{l}\text { Capital } \\
\text { goods } \\
\text { imports }\end{array}$ & $\begin{array}{c}\text { Trade } \\
\text { balance }\end{array}$ & $\begin{array}{l}\text { Current } \\
\text { account }\end{array}$ & $\begin{array}{l}\text { Interna- } \\
\text { tional } \\
\text { reserves }^{\mathrm{c}}\end{array}$ \\
\hline 1980 & 18.03 & 7.59 & 21.09 & 2.45 & $\begin{array}{l}13.47 \\
(1.74)\end{array}$ & 5.17 & -3.06 & -10.72 & 4.00 \\
\hline 1981 & 23.31 & 8.73 & 27.18 & 2.81 & $\begin{array}{l}16.80 \\
(2.23)\end{array}$ & 7.57 & -3.88 & -16.56 & 5.04 \\
\hline 1982 & 24.06 & 7.58 & 17.01 & 1.52 & $\begin{array}{l}10.99 \\
(1.97)\end{array}$ & 4.50 & 7.05 & -6.27 & 1.83 \\
\hline 1983 & 25.95 & 9.94 & 11.85 & 0.61 & $\begin{array}{c}9.04 \\
(2.82)\end{array}$ & 2.20 & 14.10 & 5.43 & 4.92 \\
\hline 1984 & 29.10 & 12.50 & 15.92 & 0.85 & $\begin{array}{l}12.50 \\
(3.75)\end{array}$ & 2.57 & 13.18 & 3.77 & 8.11 \\
\hline 1985 & 26.76 & 11.99 & 18.36 & 1.08 & $\begin{array}{l}14.11 \\
(3.83)\end{array}$ & 3.17 & 8.40 & 0.41 & 5.75 \\
\hline 1986 & 21.80 & 15.50 & 16.78 & 0.85 & $\begin{array}{l}12.98 \\
(4.35)\end{array}$ & 2.95 & 5.02 & -1.77 & 6.73 \\
\hline 1987 & 27.60 & 18.97 & 18.81 & 0.77 & $\begin{array}{l}15.41 \\
(5.51)\end{array}$ & 2.63 & 8.79 & 3.82 & 13.79 \\
\hline 1988 & 30.69 & 23.98 & 28.08 & 1.92 & $\begin{array}{l}22.13 \\
(7.81)\end{array}$ & 4.03 & 2.61 & -2.92 & 6.66 \\
\hline 1989 & 35.17 & 27.30 & 34.77 & 3.50 & $\begin{array}{l}26.50 \\
(9.33)\end{array}$ & 4.77 & 0.41 & -6.09 & 6.87 \\
\hline 1990 & 40.71 & 30.61 & 41.59 & 5.10 & $\begin{array}{c}29.71 \\
(10.32)\end{array}$ & 6.79 & -0.88 & -7.11 & 10.30 \\
\hline 1991 & 42.69 & 34.52 & 49.97 & 5.83 & $\begin{array}{c}35.54 \\
(11.78)\end{array}$ & 8.59 & -7.28 & -13.79 & 18.13 \\
\hline 1992 & 46.20 & 37.89 & 62.13 & 7.74 & $\begin{array}{c}42.83 \\
(13.93)\end{array}$ & 11.56 & -15.93 & -22.81 & 19.26 \\
\hline 1993 & 51.88 & 44.46 & 65.36 & 7.84 & $\begin{array}{c}46.46 \\
(15.13)\end{array}$ & 11.05 & -13.48 & -23.39 & 23.28 \\
\hline
\end{tabular}

Source: Authors' calculations based on data from Salinas de Gortari (1993) and unpublished data from INEGI.

a. Data for exports and imports include information from maquiladora operations.

b. Intermediate imports from maquiladoras are in parentheses.

c. International reserves are calculated using end-of-period controlled exchange rates for 1982-91 and the end-ofperiod market rates for other years. 
Table D5. Interest Rates, Inflation, and Devaluation in Mexico, 1980-93

Percent per year, except as noted

\begin{tabular}{lccrcr}
\hline Year & Cete & $\begin{array}{c}\text { Pagafe } \\
\text { rate }^{\mathrm{b}}\end{array}$ & $\begin{array}{c}\text { Stock } \\
\text { market }^{\mathrm{c}}\end{array}$ & $\begin{array}{c}\text { Consumer } \\
\text { price } \\
\text { index }^{\mathrm{d}}\end{array}$ & $\begin{array}{c}\text { Market } \\
\text { exchange } \\
\text { rate } \\
\text { (pesos per } \\
\text { dollar) }\end{array}$ \\
\hline 1980 & 22.46 & $\ldots$ & 6.72 & 29.8 & 0.00 \\
1981 & 30.77 & $\ldots$ & -34.27 & 28.7 & 12.78 \\
1982 & 45.31 & $\ldots$ & -28.72 & 98.8 & 466.17 \\
1983 & 56.59 & $\ldots$ & 265.67 & 80.8 & 8.65 \\
1984 & 48.59 & $\ldots$ & 64.49 & 59.2 & 30.13 \\
1985 & 60.18 & $\ldots$ & 177.67 & 63.7 & 113.13 \\
1986 & 86.74 & 8.80 & 320.91 & 105.7 & 104.47 \\
1987 & 95.97 & 14.50 & 124.35 & 159.2 & 143.44 \\
1988 & 69.15 & 29.80 & 100.18 & 51.7 & 3.14 \\
1989 & 44.99 & 20.80 & 98.05 & 19.7 & 16.68 \\
1990 & 34.76 & 14.50 & 50.09 & 29.9 & 9.79 \\
1991 & 19.28 & 10.90 & 124.67 & 18.8 & 4.34 \\
1992 & 15.62 & 6.20 & 24.45 & 11.9 & 1.44 \\
1993 & 14.90 & 4.08 & 48.03 & 8.0 & 0.00 \\
\hline
\end{tabular}

Source: Authors' calculations based on Banco de México (1993) and Banco de México, Indicadores Económicos, various issues.

a. A peso-denominated government bond with maturity of three months for 1980-81 and one month for other years.

b. A dollar-indexed government bond with maturity of six months for 1986-87 and one month for other years. In 1991, the dual exchange rate system disappeared, so the pagafe was replaced by the tesobano, which is indexed to the floating rate. Tesobanos are used starting in 1990.

c. Based on an index for the total Mexican stock market.

d. December over December change. 


\section{Comments and Discussion}

Guillermo Calvo: Mexico is an outstanding example of the tribulations involved in "getting your house in order" when initial conditions are bad. This session is proof of that. After an extended period of remarkable adjustment, accompanied by firm and clear-minded policymaking, we are still debating the possibility that Mexico has taken the wrong track and is derailing into low growth and eventual collapse.

The Dornbusch-Werner paper gives a brief and clear overview of key developments in the Mexican experiment, discusses two opposing hypotheses in terms of simple models, and ends with a bang. According to the authors, Mexico should devalue 20 percent "for the last time." In my comments, I will briefly discuss the two opposing views and then argue that Mexico's macroeconomic problem may be much more serious than suggested by the paper but that, happily, the solution may be ready at hand (and policymakers seem to be aware of that).

I agree with the authors that the "all's well" official view is not fully convincing. True, one must destroy to create, but it is taking a long time for growth to materialize, unemployment is rising, and savings are disturbingly low. Also, loan interest rates are dangerously high, and there seems to be a bulging share of "bad loans." To explain these facts, the authors lean toward an interpretation in which backward indexation and credit segmentation, of one sort or another, play a key role. Backward indexation contributes in a straightforward way to real appreciation as the rate of crawl slows down. On the other hand, a lower rate of devaluation-if it enjoys some credibility-lowers domestic nominal interest rates and may stimulate credit, even in cases in which the attendant real interest rate rises.

To see the last point, consider the realistic case in which borrowers pay back their debts in the form of a constant stream of nominal install- 
ments. Let the rate of devaluation be denoted by $\epsilon$; thus, abstracting from credibility and country-risk problems and assuming a zero international interest rate, the domestic nominal interest rate will also equal $\epsilon$. Now assume, for simplicity, that loans are given in perpetuity and that the rate of devaluation is expected to be constant. Hence, an individual who borrows a sum $Y$ will have to pay an installment equal to $\epsilon Y$ in perpetuity. Furthermore, normalizing the present price level to unity and assuming zero international inflation and a constant real exchange rate, one finds that domestic inflation will also be equal to $\epsilon$ and that the stream of real payments by the borrower will be given by the following expression:

$$
\epsilon Y e^{-e t}, t \geq 0,
$$

where $t=0$ is the time the loan is granted. Consequently, the higher is the rate of devaluation, $\epsilon$, the higher is the real value of the first few installments. When inflation is high, the real value of the first few installments could be exorbitantly large, thus deterring credit. Therefore, a substantially lower rate of devaluation will make credit affordable to a significantly larger segment of the population-most likely consumers. The ensuing consumption boom will put upward pressure on retailinga highly labor-intensive activity-contributing to further real appreciation of the currency.

It is worth noting that while real appreciation stemming from backward indexation is likely to be undesirable, the one stemming from credit segmentation (or desegmentation) may not be. Thus, this simple model gives some support to the authors' opinion that some of the real appreciation is warranted by sharply improved conditions in the Mexican economy. Furthermore, to the extent that backward indexation follows a mechanical formula, as in the paper, a once-and-for-all devaluation may cure excessive real appreciation.

The above model has some problems. In the first place, backward indexation makes home goods excessively expensive and, thus, consumption must be presumed to be lower than at full equilibrium. This would imply that Mexico is not saving too little, as the authors believe, but too much! Therefore, if the model will have a chance to support the view that saving is small, one needs to identify other distortions that lead individuals to overspend.

This is accomplished by the authors by building a Dornbusch-Rodri- 
guez model in which expenditure is a decreasing function of the real interest rate. A lower rate of devaluation reduces the domestic nominal interest rate but, because of backward indexation, has a smaller effect on the rate of inflation. Hence, the real interest rate falls and expenditure rises. Since the fall in the real interest rate reflects a distortion (that is, backward indexation), chances are that the resulting expenditure boom is undesirable, and Mexico is saving too little. ${ }^{1}$

In my opinion, the paper leaves out a major factor in the Mexican experiment, namely, credibility. Credibility, and its corollary, speculative behavior, is mentioned in the paper but is not given a big role. However, the evidence is clear. Interest rate differentials with the United States have persisted all through the program. They have quickly reacted to good and bad news. For example, interest rate differentials fell sharply after Mexico signed an agreement with creditor banks in 1989 and rose during the NAFTA-Perot impasse and after the recent tragic assassination. ${ }^{2}$ Interestingly, the paper shows a positive association between interest rate differentials and the trade deficit. This suggests that consumption is an increasing function of the differentials (not the other way around, as implied by how the test is conducted in the paper). Actually, there is some literature that could support such an association when stabilization-liberalization programs are not fully credible. ${ }^{3}$

To illustrate, consider a trade liberalization program that individuals think may be abandoned in the future. An example of such a program would be a unilateral trade liberalization (as in Mexico before NAFTA) in which future continuation is seen to depend on the signing of an international trade agreement or the reelection of the present political party. Since future tariffs could rise, individuals would tend to buy more imports now than they would if full credibility were the rule. This intertemporal substitution-which in practice shows up most notably in durable

1. In a representative-individual model, backward indexation is not enough to generate a consumption boom in response to a lower rate of devaluation. Calvo and Végh (1994) show that, for the boom to take place, the elasticity of substitution between tradables and nontradables should be smaller than the intertemporal rate of substitution. The latter condition, however, is rejected for a group of developing countries in Ostry and Reinhart (1992). Thus, unlike the present paper, such a model would imply that the response to a lower rate of devaluation is lower consumption.

2. Rojas-Suarez (1992).

3. Calvo (1989). 
goods-may be socially costly because it is based on an intertemporal distortion (imperfect credibility). Thus, imperfect credibility could give rise to a socially costly consumption boom. Furthermore, if the abandonment of reform is expected to be accompanied by a resurgence of inflation, or any other form of debt repudiation, interest rate differentials may simultaneously rise. ${ }^{4}$

In addition, this interpretation helps to rationalize the boom-bust nature of many stabilization programs, which may be emerging in Mexico (although one should not discount the effect of the U.S. recession). ${ }^{5}$ This is so, because in order to stay within their budget constraint, individuals are forced to slow down consumption in the future. Thus, future real wages will tend to fall, and real exchange rates will tend to rise. In this context, a modicum of downward price-wage inflexibility will result in higher unemployment and excess capacity. ${ }^{6}$ Furthermore, the bust takes place whether or not reform is carried out. It occurs because the ensuing expenditure contraction is a consequence of the initial expansion, which takes place before it is known if reforms will be carried to full fruition.

Imperfect credibility completely changes the set of effective policies. A devaluation $a$ la Dornbusch and Werner, for example, may sow the seeds of destruction. It may resolve the overappreciation problem in the short run, only to give way to a more pronounced appreciation and inflation in the future. Authorities would have revealed their taste for discretionary policy, and people may come to believe that it could happen again. Therefore, the same mechanisms that provoked the present misalignment will be set in motion again—and with a vengeance.

The Dornbusch-Werner proposal is doubly dangerous because policy credibility has not been fully established in Mexico. True, the signing of NAFTA was a big step forward, but recent developments have increased uncertainty about government response. In addition, an insidious "black hole" has been developing over the past several years, which has not yet been subject to serious discussion or analysis. I am referring

4. See Calvo and Végh (1993) for an example of a consumption boom that takes place as a result of expectations that inflation will increase in the future, even though there is no expected change in commercial policy.

5. Kiguel and Liviatan (1992).

6. This feature holds even in models where individuals are rational but are subject to a staggered-prices technology. See Calvo and Végh (1993). 
to the fragility of the present monetary and exchange rate policy in Mexico.

Let the numbers speak for themselves. Mexico's ratio of short-term highly liquid government cum banks' liabilities to net international reserves is the highest in Latin America, by a wide margin. In 1993, cetes held by the public represented close to 100 percent of net international reserves. Moreover, M2 (not including cetes) was more than four times net international reserves; for Argentina, Chile, Colombia, and Uruguay, this ratio hovered around two or three. Finally, a more comprehensive measure of short-term government cum banks' obligations like M3 (which includes cetes) was six times larger than net international reserves.

Much of M3 could quickly turn around and head for Miami. Even if one subtracts M1 from M3, the result exceeds four times net reserves, and those funds could be back in Miami in less than two months' time. If that were to happen, and the authorities were prepared to see reserves go to zero, the dollar value of the Mexican currency would have to fall to one-fourth its present value, which would require a devaluation of 300 percent. This figure would be higher if authorities do not allow net international reserves to be fully depleted.

Fortunately, the run to Miami need not take place. One way to prevent it would be for the U.S. Treasury to stand ready to buy all the cetes in private hands and bail out the Mexican banking system in case of a run. This will prevent the run from happening, at practically no cost to the U.S. Treasury. This is so because under these circumstances the run would not require a devaluation or a change in policy. Hence, there would be no advantage to shipping funds to Miami and, thus, the run would simply not take place-and the U.S. funds would never be used. ${ }^{7}$ Therefore, as promised at the outset, the solution is ready at hand and, if carefully orchestrated, the arrangement would be essentially costless and definitely improve welfare.

Recent events have shown that the U.S. Treasury is prepared to make bold moves in that direction, which is highly welcome. Thus far, however, the Treasury's determination has been tested only in connection with political developments, like the NAFTA-Perot impasse and

7. This was the rationale behind the stabilization fund set up in connection with Poland's stabilization program in 1990. It seems to have been successful. 
the recent tragic events in Mexico. The market still has to be persuaded that the Treasury will be prepared to act in a similar fashion if there is a garden-variety run against the Mexican currency provoked by, for example, an unheroic increase in U.S. interest rates. ${ }^{8}$

In my opinion, this is not the time to implement a Dornbusch-Werner devaluation. The forces that have held together the "good" equilibrium-in which Mexico is given credit for its enormous transformation effort and clear-minded policymaking-may dissipate overnight. A 20 percent devaluation (outside the present band) may get U.S. investors up in arms about the fall in the real value of their cetes, making it especially difficult for any branch of the U.S. government to rescue Mexico if a run against the Mexican peso were set into motion. The DornbuschWerner solution-taken without prior consultation and support from its NAFTA partners-may thus prove to be a poison pill for the ruling political party or its successor.

In my view, it is imperative that Mexico obtain ample support from the U.S. Treasury (the numbers recently seen in the press look rather small), making it perfectly clear that the support would be automatic and given in response to any run against the Mexican peso, not just those triggered by political events. Obviously, such a commitment by the U.S. Treasury may require a major commitment by the Mexican government to the continuation and deepening of the current reform program.

Stanley Fischer: This is the best type of paper on which to comment: it is serious; it addresses an important topic; it is well argued and persuasive, but still leaves something to discuss. Dornbusch and Werner's argument is unmistakably clear: the Mexican peso is overvalued by at least 20 percent and growth will not return unless there is a real devaluation. The devaluation can be brought about either through a formal devaluation within the pacto or by floating if the pacto partners do not agree to a formal devaluation. Given their pessimism that a formal agreement is possible, Dornbusch and Werner recommend a float and the abandonment of the pacto.

I will divide my comments into three parts. First, I take up the ques-

8. Recent press releases suggest that Mexico has received support from its NAFTA partners in the form of automatic credit lines, indicating that policymakers have a clear understanding of the situation discussed in the text. 
tion of whether the peso is significantly overvalued. I do that by trying to make the opposite case-that it is not overvalued-but conclude in favor of Dornbusch and Werner. Next, I ask what should be done about the problem. Here, I believe the Mexican government should seek a devaluation within the pacto, but that if it cannot get an agreement it should accelerate the crawl while seeking to stay in the pacto. However, if the market forces the Mexican government to devalue, it should certainly take advantage of the opportunity. Finally, I briefly reinforce Dornbusch and Werner's discussion of the benefits and dangers of using the exchange rate as the nominal anchor of a stabilization program.

\section{Is the Peso Overvalued?}

The argument for overvaluation is threefold: (a) the real exchange rate is lower than it has ever been; (b) there is a massive current account deficit; and (c) growth has come to a halt.

The real exchange rate is very low by historical standards. Relative to 1985 , which was about average for the 1970-85 period, producer prices in Mexico have risen by 37 percent compared with those in the United States. The use of the PPI may bias the argument, but Dornbusch and Werner show that other indexes give a similar message. And besides, concentrating on alternative indexes only proves the first law of overvaluation: "You know that a country is overvalued when the Finance Minister finds one real exchange rate index according to which the currency is not overvalued."

The real question is what sort of appreciation should be expected for a stabilizing and reforming country like Mexico. The Chilean real exchange rate illustrates Dornbusch and Werner's fears and hopes. The fears are those of the period up to 1982: during the 1970s the Chilean real exchange rate became progressively overvalued as the nominal exchange rate was used to anchor the stabilization; eventually, in 1982, before the debt crisis, Chile was forced to devalue. The hopes are those of the period after 1982: Chile pursued a cheap and cheapening peso policy that provided the main incentive for the exports that drove the Chilean expansion.

But other countries have seen massive real appreciations during stabilization and reform programs. Consider the Spanish and Israeli experi- 
ences. In each case, there was a large real appreciation: in Spain, domestic prices rose by one-third relative to foreign prices during the reforms of the 1970s, and then rose by another one-third from the early 1980s to 1990 (with the currency becoming overvalued). In Israel, the real exchange rate has appreciated by close to 30 percent since the 1985 stabilization, but there is no question that the current account deficit is sustainable. Growth has returned, albeit after a two-year recession during which the central bank had to persuade industry and the trade unions that it would not accommodate inflationary wage increases.

These examples show that the behavior of the real exchange rate (or relative prices) cannot by itself establish whether a currency is overvalued. The crucial question is not the level of the real exchange rate, but the sustainability of the current account, or more directly, of the exchange parity. Here is where Dornbusch and Werner are on the strongest ground. Between 1985 and 1992, the Mexican current account moved from balance to a deficit of 7 percent of GNP. This is massive by any measure.

A current account deficit of that size is not sustainable unless growth picks up remarkably. But perhaps the deficit is only temporary. That is the main argument of those who believe, or profess to believe, that the peso is not overvalued. The argument is that with NAFTA coming into effect, Mexican exports will take off, that many of the imports are capital goods that will soon pay off in increased exports, and that most of the remaining imports are intermediate goods, some of them imported as part of an inventory build-up. Thus the deficit will soon decline, both because imports of intermediates will fall and because exports will boom.

Dornbusch and Werner do not sufficiently emphasize the remarkable Mexican export boom of recent years. Between 1985 and 1992, Mexican nonoil exports increased from $\$ 12$ billion to $\$ 38$ billion, an extraordinary performance that should add confidence to predictions of continued export improvement. On the import side, the authors emphasize the dramatic proportional increase in consumption goods imports, from $\$ 1$ billion in 1985 to nearly $\$ 8$ billion in 1992 . While the percentage increase is dramatic, the dollar value of the increase in capital goods imports was larger, and imports of intermediate goods increased by $\$ 29$ billion over that period. Thus, to find the source of the import surplus, one 
needs to focus on imports of capital goods and, especially, intermediate goods. And here the argument that capital goods imports will pay off in improved growth and export performance, and that intermediate goods imports may decline, has not been resolved by the authors.

Still, the Mexican current account deficit is huge, and it is being financed largely by portfolio investment. Those investments can turn around very quickly and leave Mexico with no choice but to devalue. Of course, an increase in Mexican interest rates can stabilize investor queasiness to some extent, but higher interest rates will set growth back further. And as the European and especially Swedish experiences show. There may be no interest rate high enough to prevent an outflow and a forced devaluation.

With Mexico already heading for recession, why go through the pain of raising interest rates? To answer that question one needs to look at the state of the macroeconomy. The paper does not pay much attention to the remarkable decline in Mexican inflation in the past few years. Consumer price inflation has come down to the single digits after reaching 30 percent in 1990. That is a real achievement, which helps account for the current economic slowdown. It is not an achievement that should be given up lightly. And a maxidevaluation, carried out without the support of labor, would likely lead to wage pressures and higher inflation in Mexico. Of course, the Italian and British devaluations of 1992 give hope to every devaluer that the sleeping dogs of inflation will remain silent, but that is less likely in a country that has based its entire macroeconomic policy on a deal with labor that includes explicit understandings about the stability of the exchange rate.

The effect of a devaluation on inflation depends also on the state of excess demand in the economy. But the data do not make the life of a Mexico-watcher easy; statistics come out very late, perhaps intentionally so. The current account data are almost a year behind, and GDP data are slow to be published. It is hard to know what to make of the data on formal sector employment, which show industrial employment declining since 1990 even as aggregate industrial output continued to climb and as the official unemployment rate stayed very low. The data show a large decline in capital goods production but a large increase in exports. There can be little doubt that Mexican growth has slowed, but it is unclear by how much, and it is also unclear whether there is excess demand or excess supply in the Mexican economy. Perhaps a devalua- 
tion would take place in a weak labor market and not translate into much inflation, and perhaps it would not. The response depends on both organized labor and the informal sector.

Dornbusch and Werner are undoubtedly right to argue that a real devaluation would help growth. But that does not establish that Mexico should devalue.

\section{Should Mexico Devalue?}

The bottom line of the paper is presented in table 12. I accept the diagnosis that the problem is acute and that the desired real devaluation is about 20 percent. There are then four options. The first is to attempt to maintain the current system of a slow crawl, perhaps exploiting the bands more than has been done so far; the second is to negotiate an agreed devaluation with the pacto partners; the third is to undertake a stealth maxidevaluation; and the fourth is to float.

Continuation of the present policy has the advantage that it will, if successful, persuade investors of the benefits of buying Mexican debt and add to the credibility of Mexico's commitment to a stable exchange rate policy. It has the disadvantages that growth will take another year or two to return and that the policy may fail: at some point investors may lose their nerve and, by withdrawing their funds, bring on the devaluation that they fear. Still, by maintaining this policy, the Mexican government could step up the rate of devaluation within the band and try by agreement within the pacto to crawl a bit faster, thus hoping to bring about a gradual real devaluation.

Second, the Mexican government could try to negotiate a new pacto, one that starts with an agreed upfront devaluation and that then crawls fast enough to avoid creating a new overvaluation. This approach would have two disadvantages: it would disappoint foreign investors, and it would probably be too small, say $10-15$ percent rather than 20 percent. It has the advantage of maintaining domestic economic peace, and the further benefit of bringing growth back sooner.

The stealth maxidevaluation, say 25 percent, has the disadvantage that it would be a major defeat for the government's proclaimed exchange rate policy: it would reduce government credibility outside and inside the country. If it worked, it would bring growth back sooner but, if it failed, it could set off an inflation that would have to be fought with tight money and that would defeat its purpose. 
The decision to float would also be a major defeat that would reduce credibility and possibly upset domestic labor relations. Given the size of capital flows into and out of Mexico, it is difficult to predict where the exchange rate would settle; the float should probably be a dirty one.

Which way should Mexico go? It should start by trying to negotiate a new pacto. It seems unlikely that the labor unions would agree to a large real devaluation (that is, a nominal devaluation that is not compensated for by wage increases). In all likelihood, therefore, the government could not get more than a 10-15 percent agreed devaluation. I believe it should aim for this outcome-secretly, of course-and should take the consequences in terms of foreign loss of confidence. In the end, foreigners will invest in Mexico because it is doing well not because the government is pursuing promises that no longer make economic sense.

But if no agreement on a serious agreed devaluation is possible, then Mexico should stay with its current policies, crawling as fast as possible. It may succeed, in which case it would gain on inflation and lose on growth. It might fail and be forced to devalue. Failure would be better than success. If the market forces Mexico to devalue, then both foreigners and domestic residents will understand that the devaluation was undertaken reluctantly, under force majeure. That will help the government bring about the internal adjustments needed to ensure the success of the devaluation. And foreign investors too may be more forgiving in this case.

Credibility is a slippery concept, which should not be overvalued. The Ginaudi quote made famous by Dornbusch, that investors have the heart of a lamb, the memory of an elephant, and the legs of a deer, has not been a good guide to foreign investment behavior in the 1990s. It did not take 20 years after the debt crisis for capital flows to developing countries to resume-in some cases, like Brazil, the capital came in well before the crisis was resolved. A successful 1994 devaluation by Mexico would not keep foreign investors away for long; protracted slow growth in Mexico would.

\section{Exchange Rate Anchors}

The Mexican case, as well as that of Argentina, highlights the benefits and costs of using the nominal exchange rate to anchor a stabilization program. An exchange rate anchor helps bring inflation down fast but, if 
held in place too long, often leads to overvaluation. And then the program may reach the point at which its entire credibility rests on maintenance of an overvalued exchange rate. By that time, the stakes have been raised too high, and policymakers have taken excessive risks.

Mexico should not have allowed the exchange rate to become overvalued. It should have crawled faster over the past few years, and it should have adjusted the band with each new pacto. Of course, it has suffered from the capital inflows problem that has beset much of Latin America, but it might have avoided the trap if it had worried more about its growing overvaluation.

The lesson for the use of the exchange rate as a nominal anchor is simple: the exchange rate makes sense as a transitional nominal anchor, but, if the peg is maintained too long, it poses real dangers to the survival of a stabilization program. After a year or two, the anchor usually has to be moved. This was done successfully in Israel, which first used a fixed exchange rate for periods of 6 to 12 months, with small devaluations between periods of fixity, and then moved to its diagonal-band crawling peg system. The currency did appreciate, but that appreciation was fully consistent with the sustainability of the current account. That has not been the case in Mexico.

\section{General Discussion}

While many participants agreed that the Mexican exchange rate is overvalued and is impeding growth, there were questions about how to correct it, what the consequences would be, and how the present situation developed. Stanley Fischer questioned whether labor could be expected to accept a large devaluation, even with the carrot of a modest wage increase. And if they did not agree, it would create big political problems within the labor sector. In addition, any discussion of a large devaluation would start a stampede to get money out of the country.

Dornbusch replied that, while he could not be certain the present labor leader would accept the package he proposed, it was likely that he would. He has been committed to national unity and in the past has volunteered wage restraint to provide stability. Dornbusch reasoned that time would only reduce the chances of getting the new package accepted because labor unions were becoming more democratic, making it harder 
to strike an economywide deal as time passes. Furthermore, he saw the chances of preserving the present exchange rate from speculative attack as lower than the chances of selling devaluation with a new pacto, thus making it worth a try even if success is not assured.

On the second point, Dornbusch was confident that a plan for devaluation and a new pacto could be negotiated quickly and secretly. Business leaders would cooperate because they are so dependent on the government and would keep the pacto negotiations secret for the same reason. He noted, as an example, the Mexican stock market's failure to anticipate the privatization of the banks, even though the president had a meeting with bankers beforehand. He therefore saw little risk of a run on the peso before the announced devaluation. Werner added that a devaluation, once accomplished, was unlikely to lead to capital flight. $\mathrm{He}$ reasoned that the Mexican government would not lose credibility from a devaluation, because it would be recognized as a constructive response to a crisis. Furthermore, because Mexico is not confronting hyperinflation, the situation is much more stable than it was in Argentina, where a devaluation led to economic turmoil. The problem in Argentina, he explained, was not the devaluation itself, but uneasiness about the intentions of the incoming government. Finally, once the devaluation is done, there would no longer be a reason for investors to leave because it would be too late to avoid losses. Dornbusch added that historical experience does not suggest that a disaster would follow the devaluation, citing the recent examples of Italy, Sweden, and even Mexico itself with its recent 8 percent devaluation.

James Tobin asked why going to a floating exchange rate would not be a cleaner way to secure the needed currency alignment, particularly in light of all the difficulties surrounding a decision to devalue. Dornbusch responded that floating would pose several problems. It would lose the price-stabilizing benefits of a fixed or predictable sliding rate that was part of an incomes policy with labor, like the present pacto. It would violate the present pacto and lose the trust that went with it. And currency instability in itself would be undesirable and could lead investors to demand high interest rates, which would depress the real economy.

Some members of the panel argued that a devaluation, even if needed, should not be taken immediately. Guillermo Calvo reasoned that it would be useful to postpone the move until the Mexican govern- 
ment could secure a commitment to support the new peso exchange rate if necessary, even though he was not confident sufficient support could be obtained. Barry Bosworth pointed out that the Mexican government could lose a great deal by negotiating support from the U.S. Treasury to defend the currency because, ultimately, such support would be a loan that had to be repaid in dollars.

Nora Lustig questioned the wisdom of an immediate devaluation because of the political situation. Investor confidence is especially fragile ahead of the upcoming election and, in particular, after the assassination of the ruling party's candidate in March. Also, the likelihood that a devaluation can be negotiated through the pacto is nil under the circumstances. Lustig argued that any change to the exchange rate should be done after the elections and that even then a step-wise devaluation should be avoided. The best option is to move to some form of a floating rate and delink credibility in the government from the peso's movements.

Dornbusch responded that, in his view, the assassination provides a unique window of opportunity, a moment of "national unity" that should be seized. And he reminded the panel that the longer a devaluation is postponed, the greater the risk of a massive capital outflow and a run on the currency in fear of such a move. Thus, the belief that the government could devalue after the election makes it important to devalue before it. Furthermore, it would be much worse if Mexico were forced to devalue by a speculative attack rather than on its own initiative. In a speculative attack, there would be no chance of getting a new pacto beforehand, and the ensuing inflation uncertainty would cause investors to lose confidence. In an uncontrolled devaluation, he judged the rate might reach 30 percent, whereas it might be 12 percent after the controlled devaluation he and Werner advocate.

The panel discussed the merits of Mexico's strategy of fighting inflation. Lustig argued that Mexico had turned to the pacto because other measures, including cutting the government deficit and pegging the exchange rate without an incomes policy, had been ineffective. Fischer said that Mexico had erred by keeping the exchange rate fixed for too long. He argued that a fixed exchange rate is a good way to fight inflation for a year or two, but after that the exchange rate should be allowed to crawl at the rate of inflation. But Bosworth pointed out a built-in problem to fixing the exchange rate to fight inflation. The strategy does little 
until the currency becomes overvalued because that is when the exchange rate exercises restraint on domestic wages and prices.

Greg Mankiw raised the possibility that the Mexican government's present reluctance to devalue simply reflects a higher priority for inflation than unemployment. Fischer disagreed, noting that the government's own objectives included growth and securing political succession, both of which have been jeopardized by the mistake of allowing the real exchange rate to appreciate so much. Dornbusch added that, rather than reflecting different national priorities, the reluctance to devalue now stems from political judgments about the timing of a devaluation and the technocratic confidence of the Mexican government in its ability to control that timing.

Gary Burtless drew attention to a puzzle in the data that shows employment falling at the same time that industrial output is rising strongly and nonoil exports are soaring, though from a small base. Burtless hypothesized-and Dornbusch agreed-that this dichotomy likely reflects rapid growth in the informal sector, driven, in part, by the incentive to avoid the high payroll taxes in the formal sector. The shift of employment from the formal sector to the informal sector would show up as a decline in measured employment with no change in unemployment. Furthermore, as firms cut labor costs by purchasing intermediate inputs from the informal sector, output and productivity measures would be unreliable, because the inputs from the informal sector would not be properly counted.

Jonathan Gruber suggested that privatization might help explain three surprising developments: the fall in employment, the disappointing productivity numbers, and the consumption boom. Newly privatized firms would be likely to shed workers; privatization would increase consumption if it transferred wealth to the private sector; and productivity measurement could be distorted by production and accounting changes as ownership shifted to private hands.

Responding to these concerns about measurement, Dornbusch and Werner noted that data problems would not alter the broad facts that the exchange rate is overvalued and Mexico is in recession. Any measure of the real exchange rate would reveal a considerable peso appreciation from 1988 to 1993. Even allowing for a sizable margin of error, the employment numbers would still show falling employment. And whatever the pace of growth in the informal sector, there is a problem if the much larger formal economy is not growing. 


\section{References}

Akerlof, George A. 1990. "Procrastination and Obedience." American Economic Review, Papers and Proceedings 81(2): 1-19.

Aspe, Pedro. 1993. Economic Transformation the Mexican Way. Cambridge, Mass.: MIT Press.

Banco de México. 1993. The Mexican Economy. Mexico City: Banco de México.

- Various issues. Indicadores Económicos. Mexico City: Banco de México.

Calvo, Guillermo A. 1989. "Incredible Reforms." In Debi, Stabilization, and Development: Essays in Memory of Carlos Diaz-Alejandro, edited by Guillermo A. Calvo and others. Cambridge, Mass.: Basil Blackwell.

_ chors." Unpublished paper. International Monetary Fund (December).

. 1993. "Exchange-Rate-Based Stabilization under Imperfect Credibility." In Monetary Policy in Open Economies, edited by H. Frisch and A. Worgolter. New York: St. Martin's Press.

—. 1994. "Stabilization Dynamics and Backward-Looking Contracts." Journal of Development Economics 43(1): 59-84.

Calvo, Guillermo A., Leonardo Leiderman, and Carmen Reinhart. 1993a. "Capital Inflows and Real Exchange Rate Appreciation in Latin America: The Role of External Factors." International Monetary Fund Staff Papers 40(1): 103-51.

. 1993b. "The Capital Inflows Problem." Unpublished paper. International Monetary Fund (July).

Centro de Análisis e Investigación Económica, A.C. 1994. Informe Mensual Sobre la Economia Mexicana 11(10): 1-31.

Claessens, Stijn, Daniel Oks, and Sweder van Wijnbergen. 1994. "Interest Rates, Growth and External Debt: The Macroeconomic Impact of Mexico's Brady Deal." Discussion Paper 904. London: Centre for Economic Policy Research.

Diaz-Alejandro, Carlos F. 1965. Exchange-Rate Devaluation a Semi-Industrialized Country: The Experience of Argentina, 1955-61. Cambridge, Mass.: MIT Press.

Dornbusch, Rudiger. 1986. Dollars, Debt and Deficits. Cambridge, Mass.: MIT Press.

$\longrightarrow \rightarrow$. 1989. "Real Exchange Rates and Macroeconomics: A Selective Survey." Scandinavian Journal of Economics 91(2): 401-32.

—. 1991. "Mexican Disinflation Strategy." Unpublished paper. Massachusetts Institute of Technology (August).

1992. "Monetary Reform in Mexico." Unpublished paper. Massachusetts Institute of Technology (February).

- 1993a. Stabilization, Debt and Reform: Policy Analysis for Developing Countries. Englewood Cliffs, N.J.: Prentice Hall. 
1993b. "Mexican Competitiveness and NAFTA." Unpublished paper prepared for the Committee on Small Business, U.S. House of Representatives (May).

- 1994. "Stabilization and Monetary Reform in Latin America." In $A$ Framework for Monetary Stability, edited by J. Beaufort Wijnholds, Sylvester Eijffinger, and Lex H. Hoogduin. Boston: Kluwer Academic Publishers.

— egy." In The Chilean Economy, edited by Barry P. Bosworth, Rudiger Dornbusch, and Raúl Labán. Washington: Brookings.

$\rightarrow$ Dornbusch, Rudiger, and Stanley Fischer. 1993. "Moderate Inflation." World Bank Economic Review 7(1): 1-44.

Dornbusch, Rudiger, and Mario H. Simonsen. 1987. Inflation Stabilization with Incomes Policy Support. New York: Group of Thirty.

$\rightarrow$ Edwards, Sebastian. 1993a. "Exchange Rates as Nominal Anchors." Weltwirtschaftliches Archiv 129(1): 1-32.

- 1993b. "Exchange Rates, Inflation and Disinflation: Latin American Experiences." Working Paper 4320. Cambridge, Mass.: National Bureau of Economic Research (April).

General Agreement on Tariffs and Trade. 1993. Trade Policy Review: Mexico. Geneva: General Agreement on Tariffs and Trade.

Giavazzi, Francesco, and Marco Pagano. 1989. "Confidence Crisis and Public Debt Management.” Working Paper 2926. Cambridge, Mass.: National Bureau of Economic Research (September).

Informe Hacendario. 1993. Mexico: Secretaria de Hacienda y Credito Publico.

International Monetary Fund. 1993. Private Market Financing for Developing Countries. Washington: International Monetary Fund.

Jappelli, Tullio, and Marco Pagano. 1994. "Saving, Growth, and Liquidity Constraints." Quarterly Journal of Economics 109(1): 83-109.

$\rightarrow$ Kiguel, Miguel A., and Nissan Liviatan. 1992. "The Business Cycle Associated with Exchange Rate Stabilizations." World Bank Economic Review 6(2): 279-305.

Kouri, Pentti. 1979. "Profitability and Growth in a Small Open Economy." In Inflation and Employment in Open Economies: Essays, edited by Assar Lindbeck. Amsterdam: North Holland.

Morgan Guaranty Trust Company. Various issues. World Financial Markets. New York: Morgan Guaranty Trust Company.

Ortiz, Guillermo. 1994. "Comment on Rudiger Dornbusch: Stabilization and Monetary Reform in Latin America." In A Framework for Monetary Stability, edited by J. Beaufort Wijnholds, Sylvester Eijffinger, and Lex H. Hoogduin. Boston: Kluwer Academic Publishers.

$\rightarrow$ Ostry, Jonathan, and Carmen M. Reinhart. 1992. "Private Saving and Terms of Trade Shocks: Evidence from Developing Countries." International Monetary Fund Staff Papers 39(3): 495-517.

Presidencia de la República. 1994. Criterios Generales de Politica Económica. Mexico City: Estados Unidos Mexicanos. 
Salinas de Gortari, Carlos. 1993. Quinto Informe de Gobierno: Anexo. Mexico City: Estados Unidos Mexicanos.

Rojas-Suarez, Liliana. 1992. "An Analysis of the Linkages of Macroeconomic Policies in Mexico." In Mexico: The Strategy to Achieve Sustained Economic Growth, edited by Claudio Loser and Eliot Kalter. Occasional Paper No. 99. Washington: International Monetary Fund.

Taussig, F. W. 1927. International Trade. New York: Macmillan.

van Wijnbergen, Sweder. 1990. "Growth, External Debt and the Real Exchange Rate in Mexico." In Mexico's Search for a New Development Strategy, edited by Adele E. Wick and Dwight S. Brothers. Boulder, Colo.: Westview Press.

Végh, Carlos A. 1992. "Stopping High Inflation: An Analytical Overview." International Monetary Fund Staff Papers 39(3): 626-95. 